\title{
Upper Respiratory Tract Microbiome and Otitis Media Intertalk: Lessons from the Literature
}

\author{
Francesco Folino ${ }^{1, *}$, Luca Ruggiero ${ }^{2}$, Pasquale Capaccio ${ }^{3,4}$, Ilaria Coro ${ }^{1,2}$, Stefano Aliberti 1,5 (D), \\ Lorenzo Drago ${ }^{6}\left(\mathbb{C}\right.$, Paola Marchisio ${ }^{1,2}$ a and Sara Torretta ${ }^{3,7}(\mathbb{C}$ \\ 1 Department of Pathophysiology and Transplantation, University of Milan, 20122 Milan, Italy; \\ ilaria.coro@policlinico.mi.it (I.C.); stefano.aliberti@unimi.it (S.A.); paola.marchisio@unimi.it (P.M.) \\ 2 Pediatric Highly Intensive Care Unit, Fondazione IRCCS Ca' Granda Ospedale Maggiore Policlinico, \\ 20122 Milan, Italy; luca.ruggiero@policlinico.mi.it \\ 3 Department of Otolaryngology and Head and Neck Surgery, Fondazione IRCCS Ca' Granda Ospedale \\ Maggiore Policlinico, 20122 Milan, Italy; pasquale.capaccio@unimi.it (P.C.); sara.torretta@unimi.it (S.T.) \\ 4 Department of Biomedical Surgical Dental Science, University of Milan, 20122 Milan, Italy \\ 5 Internal Medicine Department, Respiratory Unit and Adult Cystic Fibrosis Center, Fondazione IRCCS Ca' \\ Granda Ospedale Maggiore Policlinico, 20122 Milan, Italy \\ 6 Laboratory of Clinical Microbiology, Department of Biomedical Science for Health, University of Milan, \\ 20122 Milan, Italy; lorenzo.drago@unimi.it \\ 7 Department of Clinical Sciences and Community Health, University of Milan, 20122 Milan, Italy \\ * Correspondence: francesco.folino@unimi.it
}

Received: 19 July 2020; Accepted: 31 August 2020; Published: 2 September 2020

\begin{abstract}
Otitis media (OM) is one of the most common diseases occurring during childhood. Microbiological investigations concerning this topic have been primarily focused on the four classical otopathogens (Streptococcus pneumoniae, Haemophilus influenzae, Moraxella catarrhalis and Streptococcus pyogenes) mainly because most of the studies have been conducted with culture-dependent methods. In recent years, the introduction of culture-independent techniques has allowed high-throughput investigation of entire bacterial communities, leading to a better comprehension of the role of resident flora in health and disease. The upper respiratory tract (URT) is a region of major interest in otitis media pathogenesis, as it could serve as a source of pathogens for the middle ear (ME). Studies conducted with culture-independent methods in the URT and ME have provided novel insights on the pathogenesis of middle ear diseases through the identification of both possible new causative agents and of potential protective bacteria, showing that imbalances in bacterial communities could influence the natural history of otitis media in children. The aim of this review is to examine available evidence in microbiome research and otitis media in the pediatric age, with a focus on its different phenotypes: acute otitis media, otitis media with effusion and chronic suppurative otitis media.
\end{abstract}

Keywords: otitis media; microbiota; upper respiratory tract; adenoid; middle ear; microbiota axes

\section{Introduction}

The human microbiota consists of ecological communities of commensal, symbiotic and pathogenic microorganisms that colonize several body sites, as the gastrointestinal tract, respiratory system, oral cavity, skin and female reproductive system [1]. In past years, microbiological investigations have been predominantly conducted with culture-dependent methods, therefore many sites in the human body have been considered sterile until recently. However, the introduction of culture-independent techniques has allowed investigation of entire bacterial communities [2], leading to a better comprehension of the role of resident flora in health and disease. These microorganisms and 
their products play indeed a critical role in the regulation of many homeostatic processes, including immune response and inflammation [3] and defense against pathogens [4]. A diseased alteration in the composition of these bacterial communities, defined dysbiosis, can therefore lead to many pathological conditions, including infections [5].

Most of these studies have been conducted with a marker gene analysis based on a broad-range PCR, using primers that target a segment of the 16SrRNA gene, a highly conserved region contained in bacterial genomes. This method, combined with next-generation sequencing technologies, permits the simultaneous characterization of an entire community [6]. This approach allows a fast and cost-effective analysis that provides a low-resolution view of a microbial community. However, there are also some limitations that should be taken into account when interpreting data derived from these studies: it is not possible to determine whether taxa detected are alive or dead, active or inactive, thus there is limited functional information; it is susceptible to over amplification bias, especially with low biomass samples such as middle ear fluid; as a short segment of 16SrRNA gene is amplified and sequenced, taxonomic resolution is usually limited to family or genus level; there is great variability depending on technical aspects as region selection, amplicon size, sampling, storage, sequencing approach, and bioinformatic analysis. Full-gene $16 \mathrm{~S}$ rRNA gene sequencing and metagenome and metatrascriptome analyses may overcome some of these limitations but are less adopted as they are relative expensive and complex to perform [7]. Middle ear infections and diseases are widespread in pediatric age. Acute otitis media (AOM) is the most common bacterial infection in childhood [8] and the leading cause of antibiotic prescription in pediatric patients [9]; similarly, otitis media with effusion (OME) is prevalent in the first years of life, as up to $80 \%$ of children suffer from one or more episodes by 10 years of age; however, it should be considered that the prevalence of OME varies across population and could be difficult to define accurately, as this condition is often asymptomatic [10].

The upper respiratory tract (URT) is a region of major interest in otitis media pathogenesis: According to the Pathogen Reservoir Hypothesis (PRH), the adenoid pad serves as a source of pathogens that can grow in this region and further spread to the respiratory system and middle ear, leading to infections and diseases [11-14].

The URT extends from the nostrils to the portion of the larynx above the vocal cords and harbors the highest bacterial density in the whole respiratory system [15]; however, these bacterial communities have been studied with more effort and from an ecological perspective only in recent years, after the introduction of culture-independent techniques [16].

Scientific interest has been focused on the comprehension of the characteristics of a healthy URT microbiota and the mechanism that guarantees its balance, as mounting evidence shows that resident bacteria are able to inhibit colonization and growth of otopathogens $[14,17,18]$. Those microorganisms that are essential in maintaining balance and function of a bacterial community are defined keystone species (see Table 1 for definitions of common terms used in microbiota analysis). In the URT, Dolosigranulum spp. and Corynebacterium spp. have been identified as potential keystone species, as they have been associated with respiratory health and exclusion of otopathogens in several studies [19-22].

Reconstitution of healthy microbial communities through administration of probiotics for the prevention of middle ear diseases in children is a topic of major clinical and scientific interest. Several trials have been conducted, but results lack consistency [23,24]. Deepening our knowledge on the physiological features of the URT microbiota and understanding how modifications in its balance relate to the pathogenesis of otitis media could be of remarkable importance in developing probiotic therapies. Furthermore, middle ear microbiota involvement in this field has been gaining interest in recent years, although less studies are available in comparison with URT microbiota, due to the different feasibility in collecting samples.

The aim of this review is to examine evidence available in microbiome research on otitis media in children. We will describe the most important factors that impact on microbiota development in the first years of life and that could influence the natural history of otitis media; then, we will 
focus on otitis media phenotypes and discuss evidence available on URT and middle ear microbiome in different diseases.

Table 1. Definitions of common terms used in microbiota investigations.

\begin{tabular}{|c|c|}
\hline Microbiota & $\begin{array}{l}\text { Ecological communities of commensal, symbiotic and pathogenic } \\
\text { microorganisms that colonize several body sites, as the gastrointestinal } \\
\text { tract, respiratory system, oral cavity, skin, and female reproductive system }\end{array}$ \\
\hline Microbiome & Genetic material of the microorganisms of a community \\
\hline Keystone Species & $\begin{array}{l}\text { Microorganisms with a great impact on an ecological community, } \\
\text { considered important in maintaining its organization and function }\end{array}$ \\
\hline Biodiversity & $\begin{array}{l}\text { Number of OTUs in a community and their relative abundance. It is } \\
\text { determined by richness (how many OTUs in a sample?) and evenness } \\
\text { (how equally distributed relative abundances are in a sample?) }\end{array}$ \\
\hline Alpha-Diversity & $\begin{array}{l}\text { Diversity within sample: how abundant OTUs are in relation to others } \\
\text { in the same sample? }\end{array}$ \\
\hline Beta-Diversity & Measure that compares different microbial communities \\
\hline Operational Taxonomic Unit (OTU) & $\begin{array}{l}\text { Cluster of related sequences (usually with } 97 \% \text { or more similarity) that } \\
\text { represent a taxonomic unit of a microorganism }\end{array}$ \\
\hline
\end{tabular}

\section{Methods}

The research was conducted on the PubMed database, including all evidences available until April 2020. MeSH terms as "otitis media", "microbiota", "child", "child, preschool" and "infant" were used. More articles were included combining the keywords "microbiota" and "microbiome" with terms as "acute otitis media", "otitis media with effusion", "chronic otitis media", "adenoid", "adenotonsillar", "nasopharyngeal", "middle ear".

A total of 91 potentially relevant studies were identified through this search strategy. After title and abstract analysis, 51 studies were excluded as non-pertinent, according to the following criteria: disease different from OM; site of investigation different from URT or ME; adult population; studies conducted on animals were also excluded, as the main focus of this review was to discuss evidence available in children. A total of 40 remaining articles were then selected for more detailed assessment, and 14 investigations were further excluded in this phase (see Figure 1 for more details on methods).

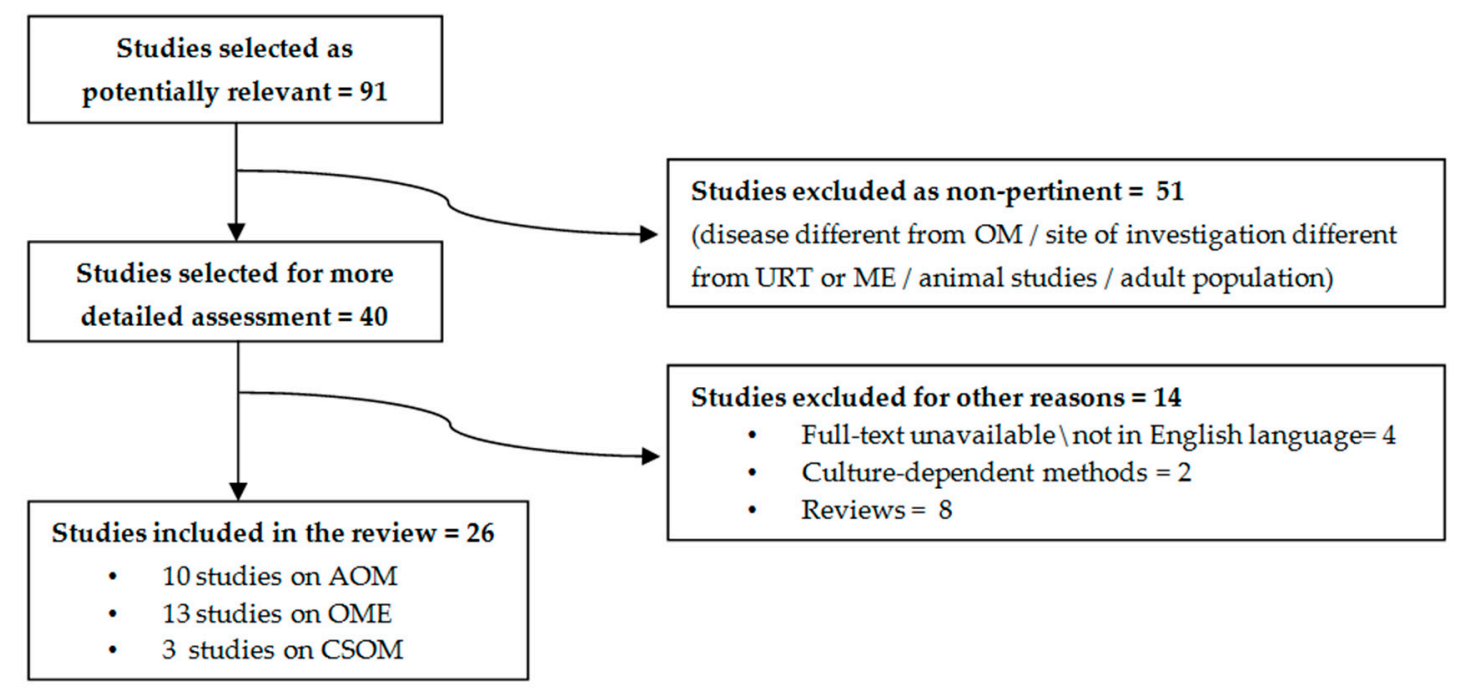

Figure 1. Search strategy conducted for this review. Legend: OM: Otitis media. AOM: Acute otitis media. OME: Otitis media with effusion. CSOM: Chronic suppurative otitis media. ME: Middle Ear. URT: Upper respiratory tract. 
After this process, 26 studies were included in this review: 10 studies on acute otitis media (AOM, 1321 subject enrolled in all studies), 13 studies on otitis media with effusion (OME, 501 subjects enrolled in all studies), 3 studies on chronic suppurative otitis media (CSOM, 217 subjects enrolled in all studies).

\section{Environmental Factors and Microbiota Development in the First Years of Life}

The microbial communities that colonize the human organism are dynamic and change throughout life under the effect of several environmental factors, but infancy and early childhood represent the critical period in shaping their composition [25,26]. These external factors can impair the homeostatic functions mediated by the microbiota, leading to immediate consequences or impacting the health status in the later stages of life [27]. This is particularly evident for the URT microbiota, as this region is interconnected with middle ear, lower respiratory tract, and gastrointestinal tract, and represents the interface between these systems and the external environment.

Immediately after birth, in the first hours of life, the URT in healthy neonates becomes colonized by microorganisms of maternal origin [28]. Niche differentiation starts in the first week of life, with a predominance of Staphylococcus spp., followed by an enrichment of Corynebacterium, Dolosigranulum, and Moraxella [29].

The first months of life are of remarkable importance in the development of URT microbial communities and their composition: Biesbroek et al. described eight distinct microbiota profiles in the URT of healthy infants, showing that a distinct bacterial profile could be identified by the sixth week of life; moreover, this early bacterial colonization plays a pivotal role in the stability of microbial communities: profiles dominated by Moraxella and Dolosigranulum/Corynebacterium are associated with a stable microbiota and with lower rates of respiratory infections in later stages of life, while less stable profiles are associated with high abundance of Haemophilus and Streptococcus [30].

Theo et al. confirmed the role of Corynebacterium and found a positive role of Alloiococcus in the first year of life in the development of URT microbial communities; moreover, authors reported data on nasopharyngeal (NP) microbiota in children with respiratory diseases, concluding that some Moraxella spp. were associated with an increased risk of disease rather than respiratory health [31].

Several environmental factors, discussed below, can influence the shaping of the URT microbiota composition in the first years of life.

\subsection{Delivery Route}

As it is generally known, children born by caesarian-section (C-section) suffer from a higher incidence of respiratory illness and morbidity in comparison with children born by vaginal delivery [32,33].

In one of the first reports concerning nasopharyngeal microbiota and route of delivery, swabs from different body sites were collected from healthy neonates immediately after birth: Authors found that undifferentiated microbial communities in vaginally delivered children were similar to maternal vaginal microbiota, while those who were born by C-section had microbial communities resembling maternal skin surface [28].

A subsequent longitudinal study on this theme analyzed nasopharyngeal swabs collected from 102 children in the first 6 months of life, showing a predominance of bacteria previously associated to microbiome stability and respiratory health in early stages of life (Moraxella, Corynebacterium, and Dolosigranulum) in children born by vaginal delivery [29]. These microorganisms are likely derived from maternal skin (Staphylococcus and Corynebacterium) [34] or from vaginal tract (Dolosigranulum, Staphylococcus, or Streptococcus) [35].

However, by contrast, another study evidenced that differences related to delivery route are transient and disappear by six weeks of age, suggesting that the development of the microbiota in the postnatal period is more related to the body site that harbors a community [36]. 


\subsection{Breastfeeding}

Breastfeeding is a significant protective factor against infections [37,38]. This effect is related not only to the presence of antibacterial substances in maternal milk [39], as it is known that breastfeeding can significantly facilitate the development of a healthy microbiota.

Biesbroek et al. showed that breastfed infants develop a bacterial profile enriched by Dolosigranulum and Corynebacterium at six weeks of age in comparison with formula fed infants; moreover, Dolosigranulum abundance was inversely associated with wheezing episodes and a number of parental reported respiratory tract infections, even after correction for feeding type. [40].

Similar data were provided by Bosch et al.: Children who suffered from a higher number of respiratory infections had an aberrant nasopharyngeal microbiota development in the first month of life, that coincided with a prolonged reduction of Dolosigranulum and Corynebacterium; authors found that breastfeeding was an independent driver of this aberrant development, as a prolonged dominance of these bacteria was observed in breastfed infants. However, similarly to delivery route, these dissimilarities are transient and disappear around six months of age [41].

\subsection{Antibiotic Therapy}

Antibiotic therapy can significantly impair composition and balance of the microbiome [42]. This is particularly relevant in pediatric age, in which antibiotic prescription and misuse is quite common [43].

In the URT, antibiotic administration causes a reduction of the abundance of potential beneficial bacteria, such as Dolosigranulum and Corynebacterium, and an increase in Haemophilus, Streptococcus, and Moraxella [31]. Moreover, in children with AOM, a recent antibiotic therapy induces a reduction of Streptococcaceae and Corynebacteriaceae and an increased abundance of Enterobacteriaceae and Pasturellaceae in the URT [44]. Subsequent longitudinal studies confirmed how antibiotic treatment can induce a reduction in the abundance of potential beneficial bacteria, as Dolosigranulum and Corynebacterium $[41,45]$.

\subsection{Pneumococcal Vaccination}

The introduction of the pneumococcal conjugate vaccination (PCV) in the pediatric population has led to an important reduction of OM episodes caused by the serotypes included in the vaccine [46]. On the other hand, the introduction of pneumococcal vaccination programs has resulted in important modifications in OM microbiology: H. influenzae has become the most common otopathogen and OM episodes caused by $M$. catarrhalis have become more frequent; moreover, serotypes not included in PCVs have been more frequently identified as causative agents of diseases [47,48].

These findings suggest that the introduction of PCVs might have induced modifications in the composition of the microbial communities in the respiratory system. However, evidence supporting these findings has been focused prevalently on otopathogens, while studies conducted with high-throughput methods and looking at whole bacterial communities in the URT are lacking and show conflicting results.

In one of the first investigations on the whole NP microbiota and AOM, Hilty et al. reported that a previous exposure to PCV-7 in children with AOM was associated with reduced abundance of commensal families (Streptococcaceae and Corynebacteriaceae) [44].

A possible influence of this vaccination on NP microbiota was later reported by Biesbroek et al. In this investigation, NP swabs were collected from healthy children who received PCV-7 and from unvaccinated children: vaccination affected the URT microbiota causing a shift in composition and structure of the bacterial community, with an increase of Veillonella, Prevotella, Fusobacterium, Leptotrichia, Actinomyces, Rothia, and non pneumococcal streptococci, in addition to an increased bacterial diversity and inter-individual variability [49]. 
Longitudinal data on this theme were further provided in another study conducted in Switzerland by Mika et al., who compared NP microbiota in healthy children who were vaccinated with PCV-7 or PCV-13, showing that those who received PCV-13 had a more diverse and stable URT microbiota and a lower pneumococcal carriage rate compared to those who received PCV-7 [50].

However, in contrast to these findings, other available studies suggest that PCV might not have such a relevant impact on the URT microbiota. Faezel et al. performed a randomized controlled trial in Kenya comparing NP microbiota of children who received a 10-valent pneumococcal vaccine vs. children who received Hepatitis A vaccine. In this longitudinal study, NP swabs were collected before the administration of the vaccine and after 6 months. The authors found that PCV did not cause any significant alteration in the abundance or prevalence of otopathogens [51].

Moreover, a more detailed longitudinal study conducted in Gambia analyzed NP swabs collected periodically from birth to the first year of life. Children were divided in three groups according to vaccination schedule: Two groups received two different types of PCV-7, while the third group was composed by unvaccinated children. Again, bacterial communities were comparable across groups, as there were no significant differences in richness, diversity, and composition. Interestingly, PCV-7 vaccination reduced the nasopharyngeal carriage of vaccine serotypes, but pneumococcal carriage remained high among vaccinated infants, probably because of an immediate expansion of non-vaccine serotypes [52].

Interesting data were provided by Andrade et al. in a complex investigation that compared 53 children vaccinated with PCV-10 vs. 27 unvaccinated children. The strength of this study is the integrated metagenomic and transcriptomic analysis: no difference were found in nasopharyngeal carriage rates of S. pneumoniae, S. aureus, H. influenzae, or M. catarrhalis by either transcriptomic ormetagenomics analysis, but unvaccinated children had higher metabolic rates for S. pneumoniae, compared to PCV-10 vaccinated children [53].

Available evidence thus suggest that PCV has a direct impact on pneumococcal carriage, which in turn might indirectly affect the whole bacterial community in the URT. However, results are conflicting: a possible explanation could be found in the variation of pneumococcal carriage rates in relation to the geographic region and socio-economic status: the effects of PCV might indeed be different while considering developed or developing countries [54].

This particular theme was investigated in a study conducted in Fiji, in which NP microbiota from two ethnic groups (iTaukei and Fijians of Indian descent) was analyzed. These groups are known to have a different carriage prevalence of $S$. pneumoniae and a different burden of pneumococcal disease, which is higher in the iTaukei population. NP swabs were collected from 132 total children belonging to the two ethnic groups that were further divided in two subgroups based on whether children had been previously vaccinated or not with PCV-7. The vaccination had no overall impact on microbial diversity or composition, but significant modifications were evident when stratifying by ethnicity: vaccinated iTaukei children had a lower relative abundance of Streptococcus and Haemophilus compared with unvaccinated ones, while vaccinated Indian descent children had a higher relative abundance of Dolosigranulum compared with those unvaccinated [55].

\subsection{Smoking}

Studies conducted in adult subjects suggest that active smoking impairs URT microbiota composition [56]. It is likely that similar effects involve the pediatric population; however, studies concerning active and passive smoking effects on URT microbiome in children are lacking.

\section{Acute Otitis Media}

Acute otitis media (AOM) is defined by the presence of fluid in the middle ear associated to signs and symptoms of acute infection. It affects the majority of children in the first 3 years of life and becomes recurrent in almost $50 \%$ of cases [10]. Recurrent acute otitis media (RAOM) is defined as four or more AOM episodes in one year or three or more episodes in 6 months [57]. 
Laufer et al. performed one of the first studies comparing NP microbiome in children with AOM to healthy children. The authors evidenced that a higher relative abundance of Corynebacterium and Dolosigranulum, in addition to Propionibacterium, Lactococcus, and Staphylococcus, was associated with a lower incidence of pneumococcal colonization and AOM. The same study showed that a less diverse and a less even microbiota was associated with colonization by S. pneumoniae, highlighting the correlation between a higher biodiversity and better outcomes [20].

These data were confirmed in a subsequent investigation conducted by the same group on 240 children aged 6 months-3 years, that evidenced that a lower biodiversity was associated with a higher colonization rate not only from S. pneumoniae but also from $H$. influenzae and M. catharralis; moreover, authors compared diversity indices between health status and during an acute upper respiratory infection (URTI), showing that biodiversity was significantly higher in healthy children than during disease [19].

These findings on biodiversity during URTI are coherent with data provided by Hilty et al. that evidenced how NP bacterial density is lower in children during an AOM episode compared with the same in healthy status. Moreover, interesting insights were provided on how the infants' microbiota undergoes changes during an AOM episode, as the classical otopathogens predominated over commensal families (Staphylococcaceae, Flavobacteriaceae, Carnobacteriaceae, and Comamonadaceae) [44].

In 2017 Chonmaitree et al. performed a longitudinal study on 139 healthy neonates, followed since birth for the first 12 months of life or until the occurrence of the first AOM episode, collecting 971 swabs performed monthly and during an URTI or AOM. In particular, as it is known that URTI often precedes an AOM episode, authors studied the characteristics of the NP microbiome during transitional phase from URTI to AOM. Data revealed that an unstable microbiota during an URTI episode with the predominance of otopathogens were associated with the occurrence of symptomatic viral infection and with a higher risk of transition from URTI to AOM. Interestingly, otopathogens were not predominant during otherwise asymptomatic viral infections [45].

Evidence on otitis-prone children, i.e., those already suffering for RAOM were provided by Dirain et al.: Authors compared the microbial flora on adenoid tissue in a small group of subjects undergoing adenoidectomy for RAOM $(n=5)$ or obstructive sleep apnea (OSA) $(n=5)$, finding that the relative abundance of $S$. pneumoniae and $M$. catharralis was higher in the RAOM group [58].

A complex study with a higher sample size was subsequently performed on an Australian population, comparing NP microbiome of 103 healthy children vs. 93 otitis-prone children undergoing grommet insertion for RAOM, in order to identify potential protective genera. This investigation confirmed the pivotal role of Dolosigranulum and Corynebacterium in NP microbiome, as these two genera have been found to be significantly more abundant in the NP of healthy children compared with otitis-prone children. As for biodiversity, in contrast with previous findings, this study found that otitis-prone children had a significantly more diverse microbiome than controls. In addition, authors analyzed middle ear fluid (MEF) microbiome collected from children undergoing surgery from RAOM and performed a paired comparison with the NP microbiome of the same subject. Results showed that these two niches were not highly concordant: In particular, the interesting data is that Alloiococcus and Turicella have been found to be abundant in MEF but almost absent in the NP [22].

The MEF microbiome during an AOM episode was further investigated on 79 subjects aged 5-42 months. This report confirmed that the classical otopathogens are the predominant species in MEF during AOM: S. pneumoniae was dominant in $16 \%$ of samples, $H$. influenzae in $17 \%$, and M. catarrhalis in 5.6\%; moreover, Turicell aotitidis was detected as a clearly dominant bacteria in two samples, suggesting that it could be a rare but true causative agent; Alloiococcus otitidis was detected only in 3 samples; Staphylococcus auricolaris was predominant in two samples, but authors speculated that this finding could be related to potential contamination from the external auditory canal (EAC); however, A. otitidis and T. otitidis could be also related to EAC contamination [59].

$\mathrm{Xu}$ et al. compared the MEF microbiota during AOM episode to the NP microbiota analyzed on nasal wash (NW) samples: A significantly higher abundance of A. otitidis was detected in MEF 
during AOM, compared with NW in health and disease; authors concluded that the ME could harbor a resident microbiome that becomes different from NP after the onset of an infection. Moreover, $\mathrm{NP}$ microbiome was analyzed prior to the onset of AOM vs. at AOM onset: In line with previous data, NP microbiome during health was significantly more diverse than during AOM [60].

Paired analysis of NP and MEF microbiome during an AOM episode was subsequently performed on a larger population, collecting $286 \mathrm{NP}$ swabs in children aged 0-6 years; 42/286 episodes were characterized by spontaneous tympanic membrane perforation (STMP), and thus, MEF microbiome was analyzed in these cases. Authors found that diversity was strictly related to age: in particular, older children had a higher richness and showed more personalized bacterial profiles, that develop toward the end of the sixth year of life. The transition to an adult-like microbiome appeared in children older than 3 years and was defined by an increase in Staphylococcaceae and Corynebacteriaceae. Furthermore, authors found concordance between NP and MEF microbiome when the predominant bacteria in MEF was S. pyogenes, H. influenzae, or S. pneumoniae. However, even this event appeared to be age-related, as the concordance between NP and MEF microbiome became weaker as children got older. Authors thus concluded that the NP microbiota does not necessarily resembles the one in ME: The URT in children with AOM serves as a moderate proxy for MEF at a very young age but becomes more diverse at a more advanced age [61].

The most frequently observed complication of AOM in clinical practice is the spontaneous tympanic membrane perforation (STMP) [62]. However, evidence on microbiota in children with history of RAOM with STMP is lacking. We believe that this condition represents a distinct phenotype of disease in otitis-prone children [63], and more effort should be directed to this category of patients, since their clinical management is often very challenging, and the most important AOM preventive measurements are often less effective [64-66].

Man et al. conducted a study on 94 children with tympanostomy tubes who suffered from ear discharge. In this case, authors observed a substantial concordance between paired NP and MEF microbiota, thus supporting the pathogen reservoir hypothesis: in particular, Pseudomonas aeruginosa, Staphylococcus aureus, Streptococcus pyogenes, Turicella otitidis, Klebsiella pneumoniae, and Haemophilus spp. were correlated between these two sites. Moraxella spp., Streptococcus pneumoniae, and Corynebacterium/Dolosigranulum were predominant in NP rather than in MEF, confirming their role as keystone bacteria of the URT; by contrast, Turicella, P. aeruginosa and S. aureus were strongly associated to MEF. Of interest, abundance of Corynebacterium and Dolosigranulum in NP related to a shorter course of the disease and better clinical outcomes [67].

Evidence available on AOM display that Dolosigranulum and Corynebacterium might act as potential keystone taxa in the URT, as they have been associated to a healthy status and to a lower colonization rate by otopathogens such as S. pneumoniae. Moreover, studies conducted on MEF identify A. otitidis and T. otitidis as possible novel otopathogens, although the theme of sample contamination from the EAC deserves major clarification.

An overview on microbiome study in AOM previously discussed is reported in Table 2. 
Table 2. Overview of investigations on microbiota and acute otitis media discussed in this review.

\begin{tabular}{|c|c|c|c|c|c|}
\hline $\begin{array}{c}\text { Title (Year of Publication) } \\
\text { [Ref] }\end{array}$ & Study Design & N. of Subjects & Age & Site of Investigation & Main Findings \\
\hline $\begin{array}{l}\text { Microbial Communities of } \\
\text { the Upper Respiratory Tract } \\
\text { and Otitis Media in Children } \\
\qquad(2011) \\
{[20]}\end{array}$ & $\begin{array}{c}\text { Comparison of NP microbial } \\
\text { communities in children with and } \\
\text { without OM }\end{array}$ & $\begin{array}{c}108 \\
\text { (25 with AOM; } \\
83 \text { without AOM) }\end{array}$ & 6-78 m & NP & $\begin{array}{l}\text { - Microbial communities with S. pneumoniae were } \\
\text { significantly less diverse and less even } \\
\text { Higher relative abundance of Corynebacterium } \\
\text { and Dolosigranulum, in addition to } \\
\text { Propionibacterium, Lactococcus, and Staphylococcus, } \\
\text { was associated with a lower incidence of } \\
\text { pneumococcal colonization and lower risk } \\
\text { of AOM }\end{array}$ \\
\hline $\begin{array}{l}\text { Nasopharyngeal Microbiota } \\
\text { in Infants with Acute Otitis } \\
\text { Media (2012) [44] }\end{array}$ & $\begin{array}{l}\text { Comparison of NP microbial } \\
\text { communities in children with and } \\
\text { without OM }\end{array}$ & $\begin{array}{c}163 \\
\text { (153 with AOM; } \\
10 \text { without AOM) }\end{array}$ & $<2 \mathrm{y}$ & NP & $\begin{array}{l}\text { - NP bacterial density was lower during an AOM } \\
\text { episode in comparison to health } \\
\text { Otopathogens predominated over commensal } \\
\text { families during AOM }\end{array}$ \\
\hline $\begin{array}{l}\text { Upper Respiratory Tract } \\
\text { Microbial Communities, Acute } \\
\text { Otitis Media Pathogens, } \\
\text { and Antibiotic Use in Healthy } \\
\text { and Sick Children (2012) [19] }\end{array}$ & $\begin{array}{l}\text { Comparison of NP microbial } \\
\text { communities in healthy children } \\
\text { vs. children with URTI with and } \\
\text { without concurrent AOM }\end{array}$ & $\begin{array}{c}240 \\
\text { (73 healthy subjects; } \\
95 \text { subjects with URTI without } \\
\text { concurrent AOM; } \\
72 \text { subjects with URTI with } \\
\text { concurrent AOM) }\end{array}$ & $6 \mathrm{~m}-3 \mathrm{y}$ & $\mathrm{NP}$ & $\begin{array}{l}\text { - } \quad \text { Lower diversity was associated with a higher } \\
\text { colonization rate by S. pneumoniae, H. influenzae, } \\
\text { and M. catarrhalis } \\
\text { - } \quad \text { Biodiversity levels were significantly higher } \\
\text { in healthy children than during disease } \\
\text { - Children with antibiotic use in the past } 6 \text { months } \\
\text { and a higher abundance of Lactococcus and } \\
\text { Propionibacterium had a lower risk of AOM } \\
\text { - Children with no antibiotic use in the past } 6 \\
\text { months, a low abundance of Streptococcus and } \\
\text { Haemophilus, and a high abundance of } \\
\text { Corynebacterium and Dolosigranulum had a lower } \\
\text { risk of AOM }\end{array}$ \\
\hline
\end{tabular}


Table 2. Cont.

\begin{tabular}{|c|c|c|c|c|c|}
\hline $\begin{array}{c}\text { Title (Year of Publication) } \\
\text { [Ref] }\end{array}$ & Study Design & N. of Subjects & Age & Site of Investigation & Main Findings \\
\hline $\begin{array}{c}\text { Nasopharyngeal microbiota } \\
\text { in infants and changes during } \\
\text { viral upper respiratory tract } \\
\text { infection and acute otitis media } \\
\text { (2017) [45] }\end{array}$ & $\begin{array}{l}\text { NP microbiota analysis of } \\
\text { children followed from near birth } \\
\text { for the first } 12 \text { months of life or } \\
\text { until the occurrence of the first } \\
\text { AOM episode. } \\
\text { NP swabs collected monthly or } \\
\text { during each URTI or } \\
\text { AOM episode. }\end{array}$ & 139 patients (971 samples) & $<1 \mathrm{y}$ & $\mathrm{NP}$ & $\begin{array}{l}\text { - Bacterial diversity was lower in culture-samples } \\
\text { positive for S. pneumoniae and H. influenzae } \\
\text { compared to cultured-negative samples } \\
\text { Otopathogen colonization was related to higher } \\
\text { incidence of URTI } \\
\text { - Higher abundance of otopathogens and lower } \\
\text { abundance of Pseudomonas, Myroides, Yersinia, } \\
\text { and Sphingomonas during URTI and AOM } \\
\text { - Higher otopathogen abundance during } \\
\text { symptomatic viral infection but not during } \\
\text { asymptomatic infection } \\
\text { An unstable microbiota during URTI and } \\
\text { the predominance of otopathogens was } \\
\text { associated with a higher risk of transition from } \\
\text { URTI to AOM }\end{array}$ \\
\hline $\begin{array}{c}\text { The Adenoid Microbiome } \\
\text { in Recurrent Acute Otitis Media } \\
\text { and Obstructive Sleep Apnea } \\
\text { (2017) [58] }\end{array}$ & $\begin{array}{l}\text { Comparison of adenoid } \\
\text { microbiota in subjects undergoing } \\
\text { surgery for RAOM or OSA }\end{array}$ & $\begin{array}{l}10 \\
\text { (5 AOM; } \\
5 \text { OSA) }\end{array}$ & $2-11$ y & Adenoid & $\begin{array}{l}\text { - H. influenzae, M. catarrhalis, S. pneumoniae, } P \text {. } \\
\text { aeruginosa, and S. aureus were predominant } \\
\text { in all samples } \\
\text { - Relative abundance of S. pneumoniae and } M \text {. } \\
\text { catharralis was higher in the RAOM group } \\
\text { - The microbial profiles associated with RAOM } \\
\text { were different from, but overlapped with OSA }\end{array}$ \\
\hline $\begin{array}{c}\text { Next-Generation Sequencing } \\
\text { Combined with Specific PCR } \\
\text { Assays To Determine } \\
\text { the Bacterial 16S rRNA Gene } \\
\text { Profiles of Middle Ear Fluid } \\
\text { Collected from Children with } \\
\text { Acute Otitis Media (2017) [59] }\end{array}$ & $\begin{array}{c}\text { ME microbiota analysis during } \\
\text { AOM episodes }\end{array}$ & 79 subjects (90 samples) & $5-42 \mathrm{~m}$ & ME & $\begin{array}{l}\text { - S. pneumoniae was detected in } 31 \% \text { of samples, } H \text {. } \\
\text { influenzae in } 27 \%, M \text {. catarrhalis in } 20 \% \text {, } \\
\text { Staphylococcus spp. in } 23 \% \text {, T. otitidis in } 5.6 \%, A \text {. } \\
\text { otitidis in } 3.3 \% \\
\text { - S. pneumoniae was the dominant pathogen in } 16 \% \\
\text { of samples, H. influenzae in } 17 \% \text {, M. catarrhalis } \\
\text { in } 5.6 \%\end{array}$ \\
\hline
\end{tabular}


Table 2. Cont.

\begin{tabular}{|c|c|c|c|c|c|}
\hline $\begin{array}{l}\text { Title (Year of Publication) } \\
\text { [Ref] }\end{array}$ & Study Design & N. of Subjects & Age & Site of Investigation & Main Findings \\
\hline $\begin{array}{l}\text { A microbiome case-control } \\
\text { study of recurrent acute otitis } \\
\text { media identified potentially } \\
\text { protective bacterial genera } \\
\text { (2018) [22] }\end{array}$ & $\begin{array}{l}\text { Comparison of NP microbiota } \\
\text { between children undergoing } \\
\text { grommet insertion for RAOM } \\
\text { (cases) vs. healthy children } \\
\text { (controls); } \\
\text { analysis of ME and EAC } \\
\text { microbiota in cases }\end{array}$ & $\begin{array}{c}196 \\
(93 \text { cases; } \\
103 \text { controls) }\end{array}$ & $<5 y$ & $\begin{array}{l}\mathrm{NP} \\
\mathrm{ME} \\
\mathrm{EAC}\end{array}$ & $\begin{array}{l}\text { - Significantly higher abundance of } \\
\text { Corynebacterium and Dolosigranulum was } \\
\text { detected in NP of controls in comparison to cases } \\
\text { Paired NP and ME were not highly concordant: } \\
\text { Alloiococcus, and Turicella were abundant in ME } \\
\text { and EAC of cases and almost absent in NP of } \\
\text { both groups } \\
\text { Gemella and Neisseria were typical of the NP } \\
\text { in cases prevalent in the middle ear }\end{array}$ \\
\hline $\begin{array}{l}\text { Comparative Analysis of } \\
\text { Microbiome in Nasopharynx } \\
\text { and Middle Ear in Young } \\
\text { Children with Acute Otitis } \\
\text { Media (2019) [60] }\end{array}$ & $\begin{array}{l}\text { Comparison of NP microbiota } 1 \\
\text { to } 3 \text { weeks prior to onset of AOM } \\
\text { vs. at onset of AOM; } \\
\text { comparison of NP and ME } \\
\text { microbiome during AOM }\end{array}$ & 6 & 6-24m & $\begin{array}{l}\text { NP } \\
\text { ME }\end{array}$ & $\begin{array}{l}\text { - Significantly higher abundance of } A \text {. otitidis } \\
\text { detected in MEF during AOM compared to NP } \\
\text { in health and disease } \\
\text { NP microbiome during health had a significantly } \\
\text { higher diversity than during AOM }\end{array}$ \\
\hline $\begin{array}{l}\text { Age-Dependent Dissimilarity of } \\
\text { the Nasopharyngeal and } \\
\text { Middle Ear Microbiota } \\
\text { in Children with Acute Otitis } \\
\text { Media (2019) [61] }\end{array}$ & $\begin{array}{l}\text { NP microbiota analysis } \\
\text { during AOM; } \\
\text { Paired NP and ME microbiota } \\
\text { analysis in children with STMP }\end{array}$ & $\begin{array}{c}286 \\
\text { (42/286 MEF from STMP) }\end{array}$ & $0-6 y$ & $\begin{array}{l}\text { NP } \\
\text { ME }\end{array}$ & $\begin{array}{l}\text { - Alpha and beta diversity levels were strictly } \\
\text { related to age: older children had a higher } \\
\text { richness and more personalized bacterial profiles } \\
\text { NP and MEF microbiome were concordant when } \\
\text { MEF was dominated by S. pyogenes, H. influenzae, } \\
\text { or S. pneumoniae }\end{array}$ \\
\hline $\begin{array}{l}\text { Respiratory Microbiota Predicts } \\
\text { Clinical Disease Course of } \\
\text { Acute Otorrhea in Children } \\
\text { with Tympanostomy Tubes } \\
\text { (2019) [67] }\end{array}$ & $\begin{array}{l}\text { Paired analysis of NP and ME } \\
\text { microbiota in children with } \\
\text { otorrhea on tympanostomy tubes }\end{array}$ & 94 & $<5 \mathrm{y}$ & $\begin{array}{l}\text { NP } \\
\text { ME }\end{array}$ & $\begin{array}{l}\text { - Microbiota composition of NP and ME differed } \\
\text { significantly, although paired NP and ME } \\
\text { samples were more similar than } \\
\text { unpaired samples } \\
\text { P. aeruginosa, S. aureus, S. pyogenes, T. otitidis, K. } \\
\text { pneumoniae, and Haemophilus spp. were } \\
\text { correlated between NP and ME } \\
\text { Moraxella spp., S. pneumoniae, } \\
\text { and Corynebacterium/Dolosigranulum were } \\
\text { predominant in NP than in MEF } \\
\text { Turicella, P. aeruginosa, and S. aureus were } \\
\text { strongly associated to ME } \\
\text { - Higher abundance of Corynebacterium and } \\
\text { Dolosigranulum in NP related to better } \\
\text { clinical outcomes }\end{array}$ \\
\hline
\end{tabular}

AOM: Acute otitis media. OSA: Obstructive Sleep Apnea. RAOM: Recurrent Acute Otitis media. EAC:
Membrane Perforation. ME: Middle Ear. MEF: Middle Ear Fluid. URTI: Upper Respiratory Tract Infection 


\section{Otitis Media with Effusion}

Otitis media with effusion (OME) is defined as the presence of middle ear fluid without signs or symptoms of acute infection. It is defined chronic otitis media with effusion (COME) whether it persists for more than 3 months [10].

The first study on this topic with a high-throughput molecular approach was conducted by Liu et al., through the investigation of the microbiota of middle ear, adenoid, and tonsils in an 8-year old child with chronic middle ear effusion undergoing adenotonsillectomy and bilateral tympanic tube insertion. Middle ear microbiota was dominated by Pseudomonadaceae, and tonsil microbiota showed a predominance by Streptococcaceae; adenoid microbiota was the most complex, including Pseudomonadaceae, Streptococcaceae, Fusobacteriaceae, and Pasteurellaceae, and shared microorganisms found both in tonsils and middle ear, supporting the hypothesis that the adenoid pad could act as a reservoir for both of these sites [68].

Relevant new insights on OME were subsequently provided in an Australian study analyzing NP swabs, MEF, and adenoid specimens from 11 indigenous children undergoing surgery: MEF microbiome was characterized by low diversity indices and predominance of a single bacteria, in most cases A. otitidis, H. influenzae, or Streptococcus spp. In particular, A. otitidis was the most common taxa in MEF and was not detected in any NP or adenoid samples. Thus, authors speculated that its origin from NP was unlikely and that it could represent a typical microorganism of the ME niche; however, as A. otitidis is a known commensal of the ear canal [69], further studies were warranted to understand its role and the influence of the ear canal flora, especially in children who suffer from recurrent tympanic membrane perforations [70].

Fago-Olsen et al. analyzed microbiota of palatine tonsils and adenoids from children undergoing surgery for adenoid/tonsillar hyperplasia vs. subjects undergoing surgery for secretory otitis media (SOM), showing that several microorganisms were occasionally co-detected in both sites, but $H$. influenzae, S. pneumoniae, and M. catarrhalis were significantly more abundant in the adenoids and almost absent from palatine tonsils, indicating that adenoids but not palatine tonsils could act as main reservoir of pathogens leading to OM. However, it should be noted that this study did not include MEF microbiota analysis [71].

Data concerning dissimilarities between NP and MEF microbiome were provided in a following investigation including 10 children undergoing adenotonsillectomy and grommet insertion for OME. The authors reported that adenoid and tonsil microbiota shared a higher similarity than adenoid and ME, thus questioning the PRH in OME. According to previous findings, Alloiococcus and Turicella were detected only in MEF samples; however, the most abundant genera in middle ear were Fusobacterium and Staphylococcus [72]. These data were subsequently confirmed in an investigation by Ari et al. on a larger population of children with OME: ME microbiome was characterized by a significant predominance of Alloicoccus otitidis (44\%), Turicella otitidis (6\%), and Staphylococcus auricularis (3\%), while adenoid harbored a high relative abundance of Rothia, Staphylococcus, and Granulicatella. As for diversity indices, no significant dissimilarities in alpha-diversity were found between MEF and adenoid niches [73].

The potential role of $A$. otitidis as a key bacteria of the ME was confirmed in an investigation by Chan et al., through the analysis of paired MEF samples and adenoid swabs from children undergoing grommet insertion for OME and of adenoid swabs from healthy subjects. Data evidenced a different composition in microbial communities between paired MEF and adenoid, as 13 of the 17 most abundant genera showed a statistically significant difference in relative abundance. In particular, A. otitidis was the predominant OTU in MEF ( $23 \%$ mean relative abundance), while it was almost absent in adenoid samples $(<1 \%$ relative abundance). Interestingly, this taxa was found in greater abundance in children with unilateral effusion. Authors postulated that the dissimilarities between the MEF and adenoid microbiota could question the PRH in children with OME: Adenoidal hypertrophy and Eustachian tube dysfunction predispose to OME, but subsequent modifications in the ME environment determine 
an unbalance in the local flora with the predominance of a certain microorganism that can potentially lead to acute disease [74].

Similarly, caution when using nasopharyngeal microbiota as a proxy for ME was warranted by Boers et al. in an investigation comparing NP and ME microbiota in children with gastro-esophageal reflux (GER) associated OM vs. children who suffered from OM without GER. Authors enrolled 30 subjects with RAOM, COME or both undergoing tympanostomy tube placement, identifying Alloiooccus spp. and Turicella spp. as the most abundant taxa in MEF while absent in NP samples. As for GER, no apparent effects were found on the NP and ME microbiota in the two groups [75].

A more recent investigation conducted in a tertiary hospital in China analyzed ME and adenoid microbiota from children undergoing surgery for OME and adenoid hypertrophy (AH) vs. adenoid microbiota from subjects without ear disease undergoing adenotonsillectomy for OSA. ME was dominated by Haemophilus (14.75\%), followed by Staphylococcus $(9.37 \%)$ and Halomonas $(7.85 \%)$; moreover, in contrast with previous findings, Alloiococcus otitidis had low relative abundance in this site $(3.75 \%)$, and Turicella was not reported at all among the most abundant genera: Authors stated that these differences with previous findings could be attributable to variation in sampling methods, sample size or geographical location. Four taxa were found to be significantly differentially abundant between ME and adenoid in OME group (Streptococcus, Neisseria, Alloprevotella, and Actinobacillus), while the classical otopathogens were commonly found both in adenoid and ME in all OME patients. Adenoid microbiota in controls was composed predominantly by Haemophilus $(15.96 \%)$, Streptococcus $(13.33 \%)$, and Moraxella (12.28\%); however, no significant differences in relative abundances of these genera were found in adenoids of OME patients vs. controls. According to this data and to previous findings, authors concluded that the dissimilarities in microbial compositions between these two niches challenge the PRH in OME [76].

The potential reservoirs for ME microbiome in children with OME were investigated by Chan et al.: MEF analysis showed similar results to the previous studies, as ME was dominated by A. otitidis, followed by Haemophilus, Moraxella, Staphylococcus, and Streptococcus; the EAC microbiome was mostly constituted by A. otitidis, Staphylococcus and Pseudomonas with rare otopathogens, whereas adenoid microbiome was composed prevalently by otopathogens, with rare EAC genera such as Alloiococcus. Basing on this data and on the previous study, authors concluded that both EAC and NP could act as a reservoir for the middle ear in children with OME. However, as bacterial translocation across an intact tympanum has not been demonstrated yet, a membrane perforation (spontaneous or iatrogenic) is probably needed to allow bacteria to translocate from EAC to ME. Unfortunately, a history of previous perforations in this cohort is not available [77].

Another pivotal genera in OME pathogenesis is Haemophilus, as highlighted in a study on ME microbiome in 55 children with chronic middle ear effusion: the most abundant genera were Haemophilus (relative abundance 22.54\%), Moraxella (11.11\%), Turicella $(7.84 \%)$, Alcaligenaceae $(5.84 \%)$, Pseudomonas (5.40\%), and Alloiococcus (5.08\%). Moreover, children were grouped by age, hearing loss, and mucin type expression in MEF: Haemophilus was significantly more abundant in children with hearing loss and was associated to MEF containing MUC5B and MUC5A, suggesting a correlation between hearing loss and mucin content in relationship to Haemophilus abundance [78].

Kolbe et al. provided data on 50 children undergoing tube placement for COME with a more detailed taxonomic resolution. In contrast to previous data that observed a predominance by Alloiococcus, Moraxella, or Haemophilus in MEF, in this study, microbial communities were highly variable, and the classical otopathogens were absent in about half of the samples. Moreover, authors compared subject based on whether they had a history of lower airway disease (asthma or bronchiolitis): Haemophilus, Staphylococcus, and Moraxella were significantly more abundant in children with lower airway diseases, while Turicella and Alloiococcus were less prevalent; in addition, ME microbial communities in children with history of asthma/bronchiolitis were significantly less diverse than children who had only COME [79]. 
Nasopharyngeal microbiome is less diverse in children suffering from OME than in controls, as highlighted by two case-control studies $[80,81]$. In particular, Walker et al. showed that the nasal microbiome in children with OME is composed of a higher abundance of pathogens, with a lower abundance of commensals as alpha-hemolytic Streptococci and Lactococcus. Moreover, cluster analysis revealed that profiles dominated by Corynebacterium, Streptococcus, or Moraxella were associated with COME, while healthy children had a more mixed bacterial profile with higher abundance of commensals [81].

In conclusion, investigations on OME discussed above confirm the role of the known otopathogens, in particular $H$. influenzae, as the predominant taxa in MEF during disease. Moreover, as previously described for AOM, A. otitidis and T. otitidis are frequently identified as abundant members of the ME microbiota. Studies have so far failed to define the possible reservoir for ME microbiome, and it is not possible to exclude a sample contamination from the EAC, especially in a low biomass environment as the ME. Concerning this theme, we believe that further studies should also be focused on patients with a history of tympanic membrane perforation, which might be the entryway for microorganisms that colonize the EAC.

An overview on microbiome study in OME previously discussed is reported in Table 3. 
Table 3. Overview of investigations on microbiota and otitis media with effusion discussed in this review.

\begin{tabular}{|c|c|c|c|c|c|}
\hline $\begin{array}{l}\text { Title (Year of Publication) } \\
\text { [Ref] }\end{array}$ & Study Design & N. of Subjects & Age & Site of Investigation & Main Findings \\
\hline $\begin{array}{l}\text { The Otologic Microbiome: A } \\
\text { Study of the Bacterial } \\
\text { Microbiota in a Pediatric } \\
\text { Patient with Chronic Serous } \\
\text { Otitis Media Using 16SrRNA } \\
\text { Gene-Based Pyrosequencing } \\
\text { (2011) [68] }\end{array}$ & $\begin{array}{l}\text { Microbiota analysis in ME, adenoid, } \\
\text { and tonsil specimens from one } \\
\text { pediatric patient with chronic } \\
\text { serous otitis media undergoing } \\
\text { adenotonsillectomy and bilateral } \\
\text { tympanic tube insertion }\end{array}$ & 1 & $8 y$ & $\begin{array}{l}\text { Adenoid } \\
\text { ME } \\
\text { Tonsil }\end{array}$ & $\begin{array}{l}\text { - Pseudomonadaceae were predominant in ME } \\
\text { - Streptococcaceae were predominant in tonsil } \\
\text { Adenoid microbiota included multiple } \\
\text { predominant bacteria: Pseudomonadaceae, } \\
\text { Streptococcaceae, Fusobacteriaceae, } \\
\text { and Pasteurellaceae } \\
\text { - Adenoid microbiota shared bacteria found both } \\
\text { in tonsils and middle ear }\end{array}$ \\
\hline $\begin{array}{l}\text { The microbiome of otitis media } \\
\text { with effusion in Indigenous } \\
\text { Australian children (2015) [70] }\end{array}$ & $\begin{array}{l}\mathrm{MEF}, \mathrm{NP} \text {, and adenoid microbiota } \\
\text { analysis in children undergoing } \\
\text { surgical treatment for OME }\end{array}$ & 11 & $3-9 y$ & $\begin{array}{l}\text { NP } \\
\text { Adenoid } \\
\text { ME }\end{array}$ & $\begin{array}{l}\text { ME microbiota was dominated by A. otitidis, } H \text {. } \\
\text { influenzae, or Streptococcus spp. } \\
\text { A. otitidis was the most common OTU in MEF } \\
\text { and was not detected in any NP or } \\
\text { adenoid samples } \\
\text { - Streptococcus spp., H. influenzae, and M. } \\
\text { catarrhalis were common to all sample types }\end{array}$ \\
\hline $\begin{array}{l}\text { The Microbiome of Otitis Media } \\
\text { with Effusion (2016) [74] }\end{array}$ & $\begin{array}{l}\text { ME and adenoid microbiota } \\
\text { analysis in children undergoing } \\
\text { adenoidectomy with ventilation } \\
\text { tube insertion for chronic OME. } \\
\text { Adenoid microbiota analysis from } \\
\text { healthy subjects enrolled as controls }\end{array}$ & $\begin{array}{l}33 \\
\text { (23 subjects with OME; } \\
10 \text { healthy controls) }\end{array}$ & $\begin{array}{l}\text { OME group: } \\
1-8 \text { y } \\
\text { Control group: } \\
1-12 \text { y }\end{array}$ & $\begin{array}{l}\text { ME } \\
\text { Adenoid }\end{array}$ & $\begin{array}{l}\text { - ME microbiota was dominated by A. otitidis (23\% } \\
\text { mean relative abundance), Haemophilus (22\%), } \\
\text { Moraxella ( } 5 \% \text { ), and Streptococcus (5\%) } \\
\text { Different microbial composition between paired } \\
\text { MEF and adenoid: } 13 / 17 \text { of the most abundant } \\
\text { genera showed a statistically significant } \\
\text { difference in relative abundance } \\
\text { A. otitidis was the predominant OTU in MEF } \\
\text { (23\% mean relative abundance), while it was } \\
\text { almost absent in adenoid samples ( }<1 \% \\
\text { relative abundance) }\end{array}$ \\
\hline $\begin{array}{l}\text { The Relationship of the Middle } \\
\text { Ear Effusion Microbiome to } \\
\text { Secretory Mucin Production } \\
\text { in Pediatric Patients with } \\
\text { Chronic Otitis Media (2016) [78] }\end{array}$ & $\begin{array}{l}\text { Microbiota analysis and mucin } \\
\text { detection in MEF collected from } \\
\text { children undergoing myringotomy } \\
\text { with tympanostomy tube } \\
\text { placement for chronic OME }\end{array}$ & 55 & 3-176 m & ME & $\begin{array}{l}\text { - The most abundant genera were Haemophilus } \\
\text { (relative abundance 22.54\%), Moraxella (11.11\%), } \\
\text { Turicella (7.84\%), Alcaligenaceae (5.84\%), } \\
\text { Pseudomonas (5.40\%), and Alloiococcus (5.08\%) } \\
\text { - Haemophilus was significantly more abundant } \\
\text { in children with hearing loss and was associated } \\
\text { to samples containing secretory mucins as } \\
\text { MUC5B and MUC5A }\end{array}$ \\
\hline
\end{tabular}


Table 3. Cont

\begin{tabular}{|c|c|c|c|c|c|}
\hline $\begin{array}{l}\text { Title (Year of Publication) } \\
\text { [Ref] }\end{array}$ & Study Design & N. of Subjects & Age & Site of Investigation & Main Findings \\
\hline $\begin{array}{l}\text { Identification of the Bacterial } \\
\text { Reservoirs for the Middle Ear } \\
\text { Using Phylogenic Analysis } \\
\text { (2017) [77] }\end{array}$ & $\begin{array}{l}\text { ME and EAC microbiota analysis } \\
\text { in children undergoing surgery for } \\
\text { OME. } \\
\text { Adenoid pad and ME microbiota } \\
\text { analysis data were included from } \\
\text { a previous study }\end{array}$ & 18 & $1-14 y$ & $\begin{array}{l}\text { ME } \\
\text { EAC }\end{array}$ & $\begin{array}{l}\text { - The MEF microbiota was dominated by A. } \\
\text { Otitidis (37.5\%), Haemophilus (14.4\%), Moraxella } \\
(10.0 \%) \text {, Staphylococcus }(8.2 \%) \text {, and Streptococcus } \\
(3.8 \%) \\
\text { - The EAC had a high abundance of Alloiococcus } \\
(58.0 \%) \text {, Staphylococcus }(20.8 \%) \text {, and Pseudomonas } \\
\text { (3.2) with rare otopathogens } \\
\text { The adenoid microbiota had a high abundance of } \\
\text { otopathogens with rare EAC genera: Alloiococcus } \\
(0.1 \% \text { vs. } 28.9 \%), \text { Haemophilus }(25.2 \% \text { vs. } 18.2 \%) \text {, } \\
\text { Staphylococcus }(0.2 \% \text { vs. } 10.8 \%) \text {, Streptococcus } \\
(12.7 \% \text { vs. } 4.2 \%) \text {, and Pseudomonas (0 } \\
\text { vs. } 2.1 \% \text {, respectively) }\end{array}$ \\
\hline $\begin{array}{l}\text { Pathogen reservoir hypothesis } \\
\text { investigated by analyses of } \\
\text { the adenotonsillar and middle } \\
\text { ear microbiota (2018) [72] }\end{array}$ & $\begin{array}{l}\text { Adenoid, middle ear, and tonsil } \\
\text { microbiota analysis in children } \\
\text { undergoing surgical treatment for } \\
\text { OME }\end{array}$ & 10 & $5-10 y$ & $\begin{array}{l}\text { Adenoid } \\
\text { ME } \\
\text { Tonsil }\end{array}$ & $\begin{array}{l}\text { - The most abundant genera in all sites were } \\
\text { Fusobacterium, Haemophilus, Neisseria, } \\
\text { and Porphyromonas } \\
\text { - Higher proportion of Haemophilus and Moraxella } \\
\text { in the adenoid than ME } \\
\text { - Alloiococcus and Turicella were detected only } \\
\text { in MEF samples } \\
\text { - Adenoid and tonsil microbiota shared a higher } \\
\text { similarity than adenoid and ME }\end{array}$ \\
\hline $\begin{array}{l}\text { Characterization of } \\
\text { the nasopharyngeal and middle } \\
\text { ear microbiota } \\
\text { in gastroesophageal } \\
\text { reflux-prone versus } \\
\text { gastroesophageal reflux } \\
\text { non-prone children (2018) [75] }\end{array}$ & $\begin{array}{l}\text { Analysis of NP and ME microbiota } \\
\text { in children suffering from } \\
\text { GER-associated OM vs. OM only } \\
\text { undergoing surgical treatment for } \\
\text { RAOM, COME, or both }\end{array}$ & $\begin{array}{c}30 \\
\text { (9 subjects with } \\
\text { GER-associated OM; } \\
21 \text { subjects with OM without } \\
\text { GER) }\end{array}$ & $\begin{array}{c}\text { GER group 1.3-6 y } \\
\text { No GER group } \\
0.8-12-8 \mathrm{y}\end{array}$ & $\begin{array}{l}\text { NP } \\
\text { ME }\end{array}$ & $\begin{array}{l}\text { - No effect of GER on NP and ME microbiota } \\
\text { in the two groups } \\
\text { Alloiococcus spp. and Turicella spp. were the most } \\
\text { common taxa in MEF and were not detected } \\
\text { in any NP swab }\end{array}$ \\
\hline
\end{tabular}


Table 3. Cont

\begin{tabular}{|c|c|c|c|c|c|}
\hline $\begin{array}{c}\text { Title (Year of Publication) } \\
\text { [Ref] }\end{array}$ & Study Design & N. of Subjects & Age & Site of Investigation & Main Findings \\
\hline $\begin{array}{c}\text { The Adenoids but Not } \\
\text { the Palatine Tonsils Serve as a } \\
\text { Reservoir for Bacteria } \\
\text { Associated with Secretory Otitis } \\
\text { Media in Small Children (2019) } \\
\text { [76] }\end{array}$ & $\begin{array}{l}\text { Adenoid and tonsillar microbiota } \\
\text { analysis in children undergoing } \\
\text { surgical treatment for hyperplasia } \\
\text { of adenoids/tonsils without } \\
\text { infection (HP group) vs. children } \\
\text { undergoing surgery for SOM }\end{array}$ & $\begin{array}{c}28 \text { (112 samples) } \\
\text { (14 subjects in HP group; } \\
14 \text { subjects in SOM group) }\end{array}$ & $\begin{array}{l}\text { HP group } \\
24-65 \mathrm{~m} \\
\text { SOM group } \\
15-59 \mathrm{~m}\end{array}$ & $\begin{array}{l}\text { Adenoid } \\
\text { Tonsils }\end{array}$ & $\begin{array}{l}\text { - The number of OTUs detected in the adenoids } \\
\text { from the HP group was significantly lower } \\
\text { compared to the number detected in adenoids } \\
\text { from SOM group } \\
\text { - Streptococcus was the most abundant genus } \\
\text { (average 25.6\%) followed by Fusobacterium } \\
(11.1 \%) \text { and Haemophilus }(10.3 \%) \\
\text { - Microbial communities were significantly } \\
\text { different between the adenoid and tonsil samples } \\
\text { - S. pneumoniae was significantly more abundant } \\
\text { in the adenoids of HP group compared to } \\
\text { adenoids of SOM group } \\
\text { - Fusobacterium nucleatum was abundant } \\
\text { in the adenoids of HP group but was almost } \\
\text { in the adenoids of SOM group } \\
\text { The classical otopathogens (H. influenzae, S. } \\
\text { pneumoniae, and M. catarrhalis) were significantly } \\
\text { more abundant in the adenoids than } \\
\text { in the tonsils }\end{array}$ \\
\hline $\begin{array}{l}\text { Altered Middle Ear Microbiome } \\
\text { in Children with Chronic Otitis } \\
\text { Media with Effusion and } \\
\text { Respiratory Illnesses (2019) [79] }\end{array}$ & $\begin{array}{l}\text { Comparison of ME microbiota } \\
\text { children with chronic OME and } \\
\text { history of lower airways disease } \\
\text { (asthma or bronchiolitis) vs. } \\
\text { children with chronic OME without } \\
\text { history of lower airways disease }\end{array}$ & $\begin{array}{c}50 \text { (13 with history of lower } \\
\text { airway disease) }\end{array}$ & $3-176 \mathrm{~m}$ & ME & $\begin{array}{l}\text { - The ME microbiome was significantly less } \\
\text { diverse in children with lower airway disease } \\
\text { - Haemophilus, Staphylococcus, and Moraxella were } \\
\text { significantly more abundant in ME of children } \\
\text { with lower airways disease }\end{array}$ \\
\hline $\begin{array}{l}\text { Analysis of the Microbiome } \\
\text { in the Adenoids of Korean } \\
\text { Children with Otitis Media } \\
\text { with Effusion (2019) [80] }\end{array}$ & $\begin{array}{l}\text { Adenoid microbiota comparison } \\
\text { between children undergoing } \\
\text { surgery for OME vs. children } \\
\text { without undergoing surgery for } \\
\text { obstructive symptoms }\end{array}$ & $\begin{array}{c}32 \\
\text { (16 subjects with OME; } \\
16 \text { subjects without OME) }\end{array}$ & $19 \mathrm{~m}-15 \mathrm{y}$ & Adenoid & $\begin{array}{l}\text { - } \quad \text { Diversity levels were lower in the OME group } \\
\text { - Haemophilus was the most abundant } \\
\text { in the OME group } \\
\text { Prevotella, Delftia, and Corynebacterium were } \\
\text { the dominant genera in the OME group }\end{array}$ \\
\hline
\end{tabular}


Table 3. Cont

\begin{tabular}{|c|c|c|c|c|c|}
\hline $\begin{array}{c}\text { Title (Year of Publication) } \\
\text { [Ref] }\end{array}$ & Study Design & N. of Subjects & Age & Site of Investigation & Main Findings \\
\hline $\begin{array}{l}\text { The bacteriome of otitis media } \\
\text { with effusion: does it originate } \\
\text { from the adenoid? (2019) [73] }\end{array}$ & $\begin{array}{l}\text { Adenoid and ME microbiota } \\
\text { analysis in children undergoing } \\
\text { surgery for OME }\end{array}$ & 25 & $1.5-9 \mathrm{y}$ & $\begin{array}{l}\text { Adenoid } \\
\text { ME }\end{array}$ & $\begin{array}{l}\text { - ME microbiome was dominated by A. otitis } \\
\text { - }(44 \%), \text { T. otitidis (6\%), and S. auricularis (3\%) } \\
\text { Adenoid microbiome was dominated by Rothia, } \\
\text { - No statistically significant difference in alpha } \\
\text { diversity between the two niches; adenoid } \\
\text { samples clustered in the beta diversity graph }\end{array}$ \\
\hline
\end{tabular}

OME: Otitis Media with Effusion. COME: Chronic Otitis Media with Effusion. NP: Nasopharynx. ME: Middle Ear. MEF: Middle Ear Fluid. GER: Gastro-esophageal reflux. RAOM: Recurrent acute otitis media. SOM: Secretive otitis media. EAC: External auditory Canal. OTU: Operational Taxonomic Unit. OSA: Obstructive sleep apnea. 


\section{Chronic Suppurative Otitis Media}

Chronic suppurative otitis media (CSOM) is defined as a chronic inflammation of the middle ear and mastoid cavity, with recurrent or persistent ear discharge through a non-intact tympanic membrane [10]. Less evidence is available on microbial communities in pediatric patients suffering from this condition.

Neef et al. compared 24 children with CSOM undergoing mastoid surgery to 22 healthy controls undergoing ear surgery for other conditions as cochlear implantation or benign brain tumor removal. Microbiota analysis and conventional culture were performed on swabs collected from middle ear and mastoid cavity during surgery. Authors did not observe a typical bacterial profile associated to CSOM, but highlighted the limits of the conventional culture-based approach, as no bacteria were detected by culture in healthy subjects. By contrast, molecular analysis detected potential pathogens as Staphylococcus, Pseudomonas, and Haemophilus even in healthy controls. As for diversity, authors observed a major inter-personal difference among CSOM patients, whereas this finding was not observed for controls. This data supported the hypothesis that microbial communities' disruption and dysbiosis could be implicated in CSOM pathogenesis [82].

These dissimilarities among patients suffering from CSOM are age-related, as reported by Minami et al. In this investigation, middle ear swabs were collected during surgery in pediatric and adult patients undergoing tympanoplasty for wet or dry COM vs. subjects undergoing surgery from other conditions than otitis media. Proteobacteria was the predominant phylum detected in normal subjects, both adults and children. However, the normal middle ear microbiota differed significantly according to age: Authors concluded that this dissimilarity between adults and children could be related to the higher incidence of Staphylococcus (Firmicutes phylum) in adults. Subjects with active inflammation and wet COM had a lower abundance of Proteobacteria and a higher incidence of Firmicutes: Authors warranted this finding to be considered in the pathogenesis of active inflammation in COM, in relation to the potential penetration of several exogenous pathogens through a chronic perforation. On the other hand, microbiome of dry COM was not significantly different from normal middle ear [83].

Santos-Cortez et al. previously performed an investigation comparing ME and EAC microbiome in 16 indigenous Filipino subject with chronic tympanic membrane perforation, showing that the microbial communities between these two niches were similar, probably due to a cross-contamination process through the perforated eardrum. Moreover, authors investigated microbiota composition in subjects who were carrier of the A2ML1 gene, which encodes an alpha-2 macroglobulin-like 1 protein, previously identified as a genetically determined risk factor for of otitis media [84]. Authors detected a higher relative abundance of Fusobacterium, Porphyromonas, Peptostreptococcus, Parvimonas, and Bacteroides in the ME of A2ML1-carrier patients, while Alloiococcus, Staphylococcus, Proteus, and Haemophilus were more abundant in ME of non-carrier subjects. Authors speculated that the expected loss-of-function of A2ML1 protein could influence ME microbiota composition promoting survival and growth of specific microorganism. This findings warrant further investigations on the relationship between host genotype and microbiota in OM [85].

Evidence on CSOM is lacking and does not show peculiar features of microbial communities in this OM phenotype. Moreover, investigations discussed above include both adults and children, thus it is difficult to draw any general conclusion in the pediatric population. The penetration of microorganisms residing in the EAC from the chronic tympanic membrane perforation has been considered in the pathogenesis of the active inflammation in CSOM, but further studies are needed to define with major detail this aspect.

An overview on microbiome study in CSOM previously discussed is reported in Table 4. 
Table 4. Overview of investigations on microbiota and chronic suppurative otitis media discussed in this review.

\begin{tabular}{|c|c|c|c|c|c|}
\hline $\begin{array}{c}\text { Title (Year of Publication) } \\
\text { [Ref] }\end{array}$ & Study Design & N. of Subjects & Age & Site of Investigation & Main Findings \\
\hline $\begin{array}{l}\text { Molecular Microbiological } \\
\text { Profile of Chronic Suppurative } \\
\text { Otitis Media (2016) [82] }\end{array}$ & $\begin{array}{c}\text { Comparison of ME and } \\
\text { mastoid microbiota } \\
\text { in patients with CSOM } \\
\text { undergoing surgery vs. } \\
\text { healthy controls }\end{array}$ & $\begin{array}{c}46 \\
\text { (24 subjects with CSOM; } \\
22 \text { healthy subjects) }\end{array}$ & $6 \mathrm{~m}-85 \mathrm{y}$ & $\begin{array}{c}\text { ME } \\
\text { Mastoid cavity }\end{array}$ & $\begin{array}{l}\text { - No typical bacterial profile associated to CSOM } \\
\text { - No bacteria were detected by culture in healthy } \\
\text { subjects, while molecular analysis detected } \\
\text { potential pathogens such as Staphylococcus, } \\
\text { Pseudomonas, and Haemophilus } \\
\text { - Inter-personal difference in diversity levels } \\
\text { among CSOM patients but not among controls }\end{array}$ \\
\hline $\begin{array}{l}\text { Microbiomes of the Normal } \\
\text { Middle Ear and Ears with } \\
\text { Chronic Otitis Media (2017) [83] }\end{array}$ & $\begin{array}{l}\text { ME microbiota analysis } \\
\text { in patients undergoing } \\
\text { tympanoplasty for wet or } \\
\text { dry COM vs. subjects } \\
\text { undergoing surgery from } \\
\text { other conditions than } \\
\quad \text { otitis media }\end{array}$ & $\begin{array}{c}155 \\
\text { (67 healthy subjects; } \\
44 \text { subjects with COM } \\
\text { without active infection; } \\
44 \text { subjects with COM } \\
\text { with active infection) }\end{array}$ & $1-84 y$ & ME & $\begin{array}{l}\text { The normal middle ear microbiota differed } \\
\text { significantly according to age: in particular, } \\
\text { a higher incidence of Staphylococcus (Firmicutes } \\
\text { phylum) was detected in adults } \\
\text { - Microbiome of dry COM was not significantly } \\
\text { different from normal middle ear } \\
\text { - Lower abundance of Proteobacteria and higher } \\
\text { incidence of Firmicutes in subjects with active } \\
\text { inflammation and wet COM }\end{array}$ \\
\hline $\begin{array}{l}\text { Middle ear microbiome } \\
\text { differences in indigenous } \\
\text { Filipinos with chronic otitis } \\
\text { media due to a duplication } \\
\text { in the A2ML1 gene (2016) [85] }\end{array}$ & $\begin{array}{l}\text { ME and EAC microbiota } \\
\text { analysis in indigenous } \\
\text { Filipinos with chronic } \\
\text { otitis media; comparison } \\
\text { of microbial communities } \\
\text { in subjects carriers of } \\
\text { A2ML1 variant vs. non } \\
\text { carrier subjects }\end{array}$ & $\begin{array}{l}16 \\
\text { (11 subjects carriers of } \\
\text { A2ML1 variant) }\end{array}$ & $4-24 y$ & $\begin{array}{l}\text { ME } \\
\text { EAC }\end{array}$ & $\begin{array}{l}\text { - Microbial communities between ME and EAC } \\
\text { were similar } \\
\text { Higher relative abundance of Fusobacterium, } \\
\text { Porphyromonas, Peptostreptococcus, Parvimonas, } \\
\text { and Bacteroides in the ME of } \\
\text { A2ML1-carrier patients } \\
\text { - Higher relative abundance of Alloiococcus, } \\
\text { Staphylococcus, Proteus, and Haemophilus in ME of } \\
\text { non-carrier subjects }\end{array}$ \\
\hline
\end{tabular}

CSOM: Chronic Suppurative Otitis Media. COM: Chronic Otitis Media. ME: Middle Ear. EAC: External auditory canal. 


\section{Probiotic Therapy}

Prevention of OM in children represents one of the most difficult aspects in the clinical management of these patients.

Restoration of dysbiosis through administration of probiotic strains is a preventive strategy that has gained major clinical and scientific interest in recent years in several diseases, including otitis media.

Probiotics are defined as "live microorganisms that, when administered in adequate amounts, confer a health benefit on the host" [86]. The introduction of high-throughput sequencing methods has allowed the investigation of entire bacterial communities and the identification of microorganisms associated to health status in various conditions.

As previously discussed, evidence on microbiota in children suffering from OM suggest that Corynebacterium spp. and Dolosigranulum pigrum are potential keystone taxa in the URT; thus, major interest has been directed towards these two microorganisms and their potential use as probiotics.

A detailed discussion of evidence available on probiotic therapy in OM goes beyond the scope of this review, as it has been recently extensively reviewed elsewhere.

A recent review by van den Broek et al. described novel insights on probiotic therapy in OM [87]. Basing on Koch's postulates, authors introduced the "probiotic postulates" to define the ideal probiotic strain to be used in clinical practice: The microorganism can be found in high abundance in health status and decreased abundance during disease; the microorganism can be isolated from a healthy organism and grown in pure culture; the cultured organism should promote health when introduced into a diseased organism; it should be possible to re-isolate these microorganisms as identical to the original agent from the healthy host. According to available evidence and to this postulates, authors identified Dolosigranulum as a prime candidate for the development of probiotic therapy.

However, current knowledge is still not sufficient to define probiotic efficacy for preventing OM. A recent systematic review included 13 studies on this subject, concluding that available evidence on probiotics use for the prevention of AOM is limited; among the various formulations, possible benefit could derive from nasal administration [88].

The most important limitations in evidence on this topic are poor to moderate quality of the investigations and great heterogeneity in route of administration (oral vs. intranasal), probiotic strains included in formulations, duration of therapy, and outcome measures.

\section{Conclusions}

The introduction of the modern molecular techniques and the subsequent investigations on microbial communities in the human organisms have changed our conceptions of health and disease and our approach to infectious conditions.

It is indeed well known that health and disease status are not merely determined by the presence or the absence of a pathogen but depend on a complex balance established among pathogens, resident microbiota, and host immune response.

Investigations previously described in this review have provided novel insights on the pathogenesis of middle ear diseases and led to the identification of both possible new causative agents and of potential protective bacteria, showing that imbalances in bacterial communities of the URT and ME could influence the natural history of otitis media in children.

However, scientific data on this topic are often difficult to compare because of methodological differences in specimen collection and analysis, in the site of investigation, and in data reporting. Moreover, a lack of standard diagnostic criteria for OM across countries often influences the enrollment phase and contributes to increase the heterogeneity among populations under investigation.

Another element that complicates data interpretation and deserves standardization is the use of different databases during OTUs assignment. This is a relevant issue that should be taken into consideration for two main reasons: different databases might lead to heterogeneous results; some taxa could be misclassified with certain databases, as reported for A. otitidis and T. otitidis [89].

We believe that future investigation should be focused on the following aspects: 
- Defining standard criteria of specimen collection, analysis, and data reporting, in order to facilitate data comparison across studies;

- Deepening our knowledge on the impact of various exogenous factors that have been less explored, such as active/passive smoking, vaccines, and viral infections;

- Confirming the role of Corynebacterium and/or Dolosigranulum as keystone taxa, in order to evaluate their possible use as probiotics;

- Understanding the development of URT and ME microbiota at different ages, in order to identify a potential "window of opportunity" in which therapeutic interventions as probiotic administration could be more effective, before the establishment of a stable microbial community that could be modulated with difficulty;

- Investigating the concordance between NP and ME microbiota, in order to better define the role of adenoid pad as a proxy for ME;

- Providing data on microbial communities in ME, which is no longer considered a sterile site;

- Defining with major detail the features of NP and ME microbial communities in different OM phenotypes, in particular in children with recurrent STMP.

Author Contributions: P.M. and S.T. conceived the paper; F.F. conducted the literature search and wrote the manuscript; I.C. contributed to the literature search; P.M., S.T., L.D., P.C. and S.A. revised the paper; L.R. revised the technical aspects. All authors have read and agreed to the published version of the manuscript.

Funding: This research received no external funding.

Conflicts of Interest: The authors declare no conflict of interest.

\section{References}

1. The NIH HMP Working Group; Peterson, J.; Garges, S.; Giovanni, M.; McInnes, P.; Wang, L.; Schloss, J.A.; Bonazzi, V.; McEwen, J.E.; Wetterstrand, K.A.; et al. The NIH Human Microbiome Project. Genome Res. 2009, 19, 2317-2323. [CrossRef] [PubMed]

2. Patel, A.H.; Harris, K.A.; Fitzgerald, F. What is broad-range $16 \mathrm{~S}$ rDNA PCR? Arch. Dis. Child. Educ. Pract. Ed. 2017, 102, 261-264. [CrossRef] [PubMed]

3. Samuelson, D.R.; Welsh, D.A.; Shellito, J.E. Regulation of lung immunity and host defense by the intestinal microbiota. Front. Microbiol. 2015, 6, 1085. [CrossRef] [PubMed]

4. Buffie, C.G.; Pamer, E.G. Microbiota-mediated colonization resistance against intestinal pathogens. Nat. Rev. Immunol. 2013, 13, 790-801. [CrossRef] [PubMed]

5. Honda, K.; Littman, D.R. The microbiome in infectious disease and inflammation. Annu. Rev. Immunol. 2012, 30, 759-795. [CrossRef] [PubMed]

6. Schuster, S.C. Next-generation sequencing transforms today's biology. Nat. Methods 2007, 5, 16-18. [CrossRef] [PubMed]

7. Knight, R.; Vrbanac, A.; Taylor, B.C.; Aksenov, A.; Callewaert, C.; Debelius, J.; González, A.; Kosciolek, T.; McCall, L.-I.; McDonald, D.; et al. Best practices for analysing microbiomes. Nat. Rev. Genet. 2018, 16, 410-422. [CrossRef]

8. Paradise, J.L.; Rockette, H.E.; Colborn, D.K.; Bernard, B.S.; Smith, C.G.; Kurs-Lasky, M.; Janosky, J.E. Otitis Media in 2253 Pittsburgh-Area Infants: Prevalence and Risk Factors During the First Two Years of Life. Pediatrics 1997, 99, 318-333. [CrossRef]

9. Marom, T.; Marchisio, P.G.; Tamir, S.O.; Torretta, S.; Gavriel, H.; Esposito, S. Complementary and Alternative Medicine Treatment Options for Otitis Media. Medicine 2016, 95, e2695. [CrossRef]

10. Schilder, A.G.; Chonmaitree, T.; Cripps, A.W.; Rosenfeld, R.M.; Casselbrant, M.L.; Haggard, M.P.; Venekamp, R.P. Otitis media. Nat. Rev. Dis. Prim. 2016, 2, 16063. [CrossRef]

11. Bernstein, J.M.; Reddy, M.S.; Scannapieco, F.A.; Faden, H.S.; Ballow, M. The Microbial Ecology and Immunology of the Adenoid: Implications for Otitis Media. Ann. N.Y. Acad. Sci. 1997, 830, 19-31. [CrossRef] [PubMed]

12. Nistico, L.; Kreft, R.; Gieseke, A.; Coticchia, J.M.; Burrows, A.; Khampang, P.; Liu, Y.; Kerschner, J.E.; Post, J.C.; Lonergan, S.; et al. Adenoid Reservoir for Pathogenic Biofilm Bacteria. J. Clin. Microbiol. 2011, 49, 1411-1420. [CrossRef] [PubMed] 
13. Hoa, M.; Tomovic, S.; Nistico, L.; Hall-Stoodley, L.; Stoodley, P.; Sachdeva, L.; Berk, R.; Coticchia, J.M. Identification of adenoid biofilms with middle ear pathogens in otitis-prone children utilizing SEM and FISH. Int. J. Pediatr. Otorhinolaryngol. 2009, 73, 1242-1248. [CrossRef] [PubMed]

14. Bogaert, D.; De Groot, R.; Hermans, P. Streptococcus pneumoniae colonisation: The key to pneumococcal disease. Lancet Infect. Dis. 2004, 4, 144-154. [CrossRef]

15. Man, W.H.; Piters, W.A.A.D.S.; Bogaert, D. The microbiota of the respiratory tract: Gatekeeper to respiratory health. Nat. Rev. Genet. 2017, 15, 259-270. [CrossRef] [PubMed]

16. Piters, W.A.A.D.S.; Sanders, E.A.M.; Bogaert, D. The role of the local microbial ecosystem in respiratory health and disease. Philos. Trans. R. Soc. B Biol. Sci. 2015, 370, 20140294. [CrossRef]

17. Tano, K.; Grahn-Håkansson, E.; Holm, S.E.; Hellström, S. Inhibition of OM pathogens by alpha-hemolytic streptococci from healthy children, children with SOM and children with rAOM. Int. J. Pediatr. Otorhinolaryngol. 2000, 56, 185-190. [CrossRef]

18. Tano, K.; Olofsson, C.; Grahn-Håkansson, E.; Holm, S.E. In vitro inhibition of S. pneumoniae, nontypable H. influenzae and M. catharralis by alpha-hemolytic streptococci from healthy children. Int. J. Pediatr. Otorhinolaryngol. 1999, 47, 49-56. [CrossRef]

19. Pettigrew, M.M.; Laufer, A.S.; Gent, J.F.; Kong, Y.; Fennie, K.; Metlay, J.P. Upper Respiratory Tract Microbial Communities, Acute Otitis Media Pathogens, and Antibiotic Use in Healthy and Sick Children. Appl. Environ. Microbiol. 2012, 78, 6262-6270. [CrossRef]

20. Laufer, A.S.; Metlay, J.P.; Gent, J.F.; Fennie, K.; Kong, Y.; Pettigrew, M.M. Microbial Communities of the Upper Respiratory Tract and Otitis Media in Children. mBio 2011, 2, e00245-e00310. [CrossRef]

21. Bomar, L.; Brugger, S.D.; Yost, B.H.; Davies, S.S.; Lemon, K.P. Corynebacterium accolensReleases Antipneumococcal Free Fatty Acids from Human Nostril and Skin Surface Triacylglycerols. mBio 2016, 7, 01725. [CrossRef] [PubMed]

22. Lappan, R.; Imbrogno, K.; Sikazwe, C.; Anderson, D.; Mok, D.; Coates, H.; Vijayasekaran, S.; Bumbak, P.; Blyth, C.; Jamieson, S.E.; et al. A microbiome case-control study of recurrent acute otitis media identified potentially protective bacterial genera. BMC Microbiol. 2018, 18, 13. [CrossRef] [PubMed]

23. Tano, K.; Håkansson, E.G.; Holm, S.E.; Hellström, S. A nasal spray with alpha-haemolytic streptococci as long term prophylaxis against recurrent otitis media. Int. J. Pediatr. Otorhinolaryngol. 2002, 62, 17-23. [CrossRef]

24. Marchisio, P.G.; Santagati, M.C.; Scillato, M.; Baggi, E.; Fattizzo, M.; Rosazza, C.; Stefani, S.; Esposito, S.; Principi, N. Streptococcus salivarius 24SMB administered by nasal spray for the prevention of acute otitis media in otitis-prone children. Eur. J. Clin. Microbiol. Infect. Dis. 2015, 34, 2377-2383. [CrossRef] [PubMed]

25. Costello, E.K.; Lauber, C.L.; Hamady, M.; Fierer, N.; Gordon, J.I.; Knight, R. Bacterial Community Variation in Human Body Habitats Across Space and Time. Science 2009, 326, 1694-1697. [CrossRef]

26. Thomas, S.; Izard, J.; Walsh, E.; Batich, K.; Chongsathidkiet, P.; Clarke, G.; Sela, D.A.; Muller, A.J.; Mullin, J.M.; Albert, K.; et al. The Host Microbiome Regulates and Maintains Human Health: A Primer and Perspective for Non-Microbiologists. Cancer Res. 2017, 77, 1783-1812. [CrossRef]

27. Charbonneau, M.R.; Blanton, L.V.; DiGiulio, D.B.; Relman, D.A.; Lebrilla, C.B.; Mills, D.A.; Gordon, J.I. A microbial perspective of human developmental biology. Nature 2016, 535, 48-55. [CrossRef]

28. Dominguez-Bello, M.G.; Costello, E.K.; Contreras, M.; Magris, M.; Hidalgo, G.; Fierer, N.; Knight, R. Delivery mode shapes the acquisition and structure of the initial microbiota across multiple body habitats in newborns. Proc. Natl. Acad. Sci. USA 2010, 107, 11971-11975. [CrossRef]

29. Bosch, A.A.; Levin, E.; Van Houten, M.A.; Hasrat, R.; Kalkman, G.; Biesbroek, G.; Piters, W.A.A.D.S.; De Groot, P.-K.C.; Pernet, P.; Keijser, B.J.; et al. Development of Upper Respiratory Tract Microbiota in Infancy is Affected by Mode of Delivery. EBioMedicine 2016, 9, 336-345. [CrossRef]

30. Biesbroek, G.; Tsivtsivadze, E.; Sanders, E.A.M.; Montijn, R.; Veenhoven, R.H.; Keijser, B.J.F.; Bogaert, D. Early Respiratory Microbiota Composition Determines Bacterial Succession Patterns and Respiratory Health in Children. Am. J. Respir. Crit. Care Med. 2014, 190, 1283-1292. [CrossRef]

31. Teo, S.M.; Mok, D.; Pham, K.; Kusel, M.; Serralha, M.; Troy, N.; Holt, B.J.; Hales, B.J.; Walker, M.L.; Hollams, E.; et al. The infant nasopharyngeal microbiome impacts severity of lower respiratory infection and risk of asthma development. Cell Host Microbe 2015, 17, 704-715. [CrossRef] [PubMed]

32. Guibas, G.V.; Moschonis, G.; Xepapadaki, P.; Roumpedaki, E.; Androutsos, O.; Manios, Y.; Papadopoulos, N.G. Conception viain vitrofertilization and delivery by Caesarean section are associated with paediatric asthma incidence. Clin. Exp. Allergy 2013, 43, 1058-1066. [CrossRef] [PubMed] 
33. Kristensen, K.; Fisker, N.; Haerskjold, A.; Ravn, H.; Simões, E.A.F.; Stensballe, L. Caesarean Section and Hospitalization for Respiratory Syncytial Virus Infection: A population-based study. Pediatr. Infect. Dis. J. 2015, 34, 145-148. [CrossRef] [PubMed]

34. Grice, E.A.; Segre, J.A. The skin microbiome. Nat. Rev. Genet. 2011, 9, 244-253. [CrossRef]

35. Mendling, W. Vaginal Microbiota. Adv. Exp. Med. Biol. 2016, 902, 83-93. [CrossRef]

36. Chu, D.M.; Ma, J.; Prince, A.L.; Antony, K.M.; Seferovic, M.D.; Aagaard, K.M. Maturation of the infant microbiome community structure and function across multiple body sites and in relation to mode of delivery. Nat. Med. 2017, 23, 314-326. [CrossRef]

37. Tarrant, M.; Kwok, M.K.; Lam, T.-H.; Leung, G.M.; Schooling, C.M. Breast-feeding and Childhood Hospitalizations for Infections. Epidemiology 2010, 21, 847-854. [CrossRef]

38. Duijts, L.; Jaddoe, V.W.V.; Hofman, A.; Moll, H.A. Prolonged and Exclusive Breastfeeding Reduces the Risk of Infectious Diseases in Infancy. Pediatrics 2010, 126, e18-e25. [CrossRef]

39. Labbok, M.; Clark, D.; Goldman, A.S. Breastfeeding: Maintaining an irreplaceable immunological resource. Nat. Rev. Immunol. 2004, 4, 565-572. [CrossRef]

40. Biesbroek, G.; Bosch, A.A.; Wang, X.; Keijser, B.J.F.; Veenhoven, R.H.; Sanders, E.A.; Bogaert, D. The Impact of Breastfeeding on Nasopharyngeal Microbial Communities in Infants. Am. J. Respir. Crit. Care Med. 2014, 190, 298-308. [CrossRef]

41. Bosch, A.A.T.M.; Wouter, A.A.d.S.P.; Van Houten, M.A.; Chu, M.L.J.N.; Biesbroek, G.; Kool, J.; Pernet, P.; De Groot, P.-K.C.M.; Eijkemans, M.J.C.; Keijser, B.J.F.; et al. Maturation of the Infant Respiratory Microbiota, Environmental Drivers, and Health Consequences. A Prospective Cohort Study. Am. J. Respir. Crit. Care Med. 2017, 196, 1582-1590. [CrossRef] [PubMed]

42. Sullivan, Å.; Edlund, C.; Nord, C.E. Effect of antimicrobial agents on the ecological balance of human microflora. Lancet Infect. Dis. 2001, 1, 101-114. [CrossRef]

43. Hicks, L.A.; Taylor, T.H.; Hunkler, R.J. U.S. Outpatient Antibiotic Prescribing, 2010. N. Engl. J. Med. 2013, 368, 1461-1462. [CrossRef] [PubMed]

44. Hilty, M.; Qi, W.; Brugger, S.D.; Frei, L.; Agyeman, P.; Frey, P.M.; Aebi, S.; Mühlemann, K. Nasopharyngeal Microbiota in Infants with Acute Otitis Media. J. Infect. Dis. 2012, 205, 1048-1055. [CrossRef]

45. Chonmaitree, T.; Jennings, K.; Golovko, G.; Khanipov, K.; Pimenova, M.; Patel, J.A.; McCormick, D.P.; Loeffelholz, M.J.; Fofanov, Y. Nasopharyngeal microbiota in infants and changes during viral upper respiratory tract infection and acute otitis media. PLOS ONE 2017, 12, e0180630. [CrossRef]

46. Pettigrew, M.M.; Alderson, M.R.; Bakaletz, L.O.; Barenkamp, S.J.; Hakansson, A.P.; Mason, K.M.; Nokso-Koivisto, J.; Patel, J.; Pelton, S.I.; Murphy, T.F. Panel 6: Vaccines. Otolaryngol. Neck Surg. 2017, 156 (Suppl. 4), S76-S87. [CrossRef]

47. Ngo, C.C.; Massa, H.M.; Thornton, R.B.; Cripps, A.W. Predominant Bacteria Detected from the Middle Ear Fluid of Children Experiencing Otitis Media: A Systematic Review. PLoS ONE 2016, 11, e0150949. [CrossRef]

48. Gladstone, R.A.; Jefferies, J.M.; Tocheva, A.S.; Beard, K.R.; Garley, D.; Chong, W.W.; Bentley, S.D.; Faust, S.N.; Clarke, S.C. Five winters of pneumococcal serotype replacement in UK carriage following PCV introduction. Vaccine 2015, 33, 2015-2021. [CrossRef]

49. Biesbroek, G.; Wang, X.; Keijser, B.J.; Eijkemans, R.M.; Trzcinski, K.; Rots, N.Y.; Veenhoven, R.H.; Sanders, E.A.; Bogaert, D. Seven-Valent Pneumococcal Conjugate Vaccine and Nasopharyngeal Microbiota in Healthy Children. Emerg. Infect. Dis. 2014, 20, 201-210. [CrossRef]

50. Mika, M.; Maurer, J.; Korten, I.; Allemann, A.; Aebi, S.; Brugger, S.D.; Qi, W.; Frey, U.; Latzin, P.; Hilty, M. Influence of the pneumococcal conjugate vaccines on the temporal variation of pneumococcal carriage and the nasal microbiota in healthy infants: A longitudinal analysis of a case-control study. Microbiome 2017, 5, 85. [CrossRef]

51. Feazel, L.M.; Santorico, S.A.; Robertson, C.E.; Bashraheil, M.; Scott, J.A.G.; Frank, D.; Hammitt, L.L. Effects of Vaccination with 10-Valent Pneumococcal Non-Typeable Haemophilus influenza Protein D Conjugate Vaccine (PHiD-CV) on the Nasopharyngeal Microbiome of Kenyan Toddlers. PLoS ONE 2015, 10, e0128064. [CrossRef] [PubMed]

52. Kwambana-Adams, B.A.; Hanson, B.; Worwui, A.; Agbla, S.; Foster-Nyarko, E.; Ceesay, F.; Ebruke, C.; Egere, U.; Zhou, Y.; Ndukum, M.; et al. Rapid replacement by non-vaccine pneumococcal serotypes may mitigate the impact of the pneumococcal conjugate vaccine on nasopharyngeal bacterial ecology. Sci. Rep. 2017, 7, 1-11. [CrossRef] [PubMed] 
53. Andrade, D.C.; Borges, I.C.; Bouzas, M.L.; Oliveira, J.R.; Fukutani, K.F.; Queiroz, A.T.; De Oliveira, C.I.; Barral, A.; Van Weyenbergh, J.; Nascimento-Carvalho, C. 10-valent pneumococcal conjugate vaccine (PCV10) decreases metabolic activity but not nasopharyngeal carriage of Streptococcus pneumoniae and Haemophilus influenzae. Vaccine 2017, 35, 4105-4111. [CrossRef]

54. Adegbola, R.A.; DeAntonio, R.; Hill, P.C.; Roca, A.; Usuf, E.; Hoet, B.; Greenwood, B.M. Carriage of Streptococcus pneumoniae and Other Respiratory Bacterial Pathogens in Low and Lower-Middle Income Countries: A Systematic Review and Meta-Analysis. PLoS ONE 2014, 9, e103293. [CrossRef] [PubMed]

55. Boelsen, L.K.; Dunne, E.M.; Mika, M.; Eggers, S.; Nguyen, C.D.; Ratu, F.T.; Russell, F.M.; Mulholland, E.K.; Hilty, M.; Satzke, C. The association between pneumococcal vaccination, ethnicity, and the nasopharyngeal microbiota of children in Fiji. Microbiome 2019, 7, 106. [CrossRef]

56. Charlson, E.S.; Chen, J.; Custers-Allen, R.; Bittinger, K.; Li, H.; Sinha, R.; Hwang, J.; Bushman, F.D.; Collman, R.G. Disordered Microbial Communities in the Upper Respiratory Tract of Cigarette Smokers. PLoS ONE 2010, 5, e15216. [CrossRef]

57. Teele, D.W.; Klein, J.O.; Rosner, B. Epidemiology of Otitis Media During the First Seven Years of Life in Children in Greater Boston: A Prospective, Cohort Study. J. Infect. Dis. 1989, 160, 83-94. [CrossRef]

58. Dirain, C.O.; Silva, R.C.; Collins, W.O.; Antonelli, P.J. The Adenoid Microbiome in Recurrent Acute Otitis Media and Obstructive Sleep Apnea. J. Int. Adv. Otol. 2017, 13, 333-339. [CrossRef]

59. Sillanpää, S.; Kramna, L.; Oikarinen, S.; Sipilä, M.; Rautiainen, M.; Aittoniemi, J.; Laranne, J.; Hyöty, H.; Cinek, O. Next-Generation Sequencing Combined with Specific PCR Assays To Determine the Bacterial 16S rRNA Gene Profiles of Middle Ear Fluid Collected from Children with Acute Otitis Media. mSphere 2017, 2, 00006-00017. [CrossRef]

60. Xu, Q.; Gill, S.; Xu, L.; Gonzalez, E.; Pichichero, M.E. Comparative Analysis of Microbiome in Nasopharynx and Middle Ear in Young Children With Acute Otitis Media. Front. Genet. 2019, 10, 1-7. [CrossRef]

61. Brugger, S.D.; Kraemer, J.G.; Qi, W.; Bomar, L.; Oppliger, A.; Hilty, M. Age-Dependent Dissimilarity of the Nasopharyngeal and Middle Ear Microbiota in Children With Acute Otitis Media. Front. Genet. 2019, 10, 555. [CrossRef] [PubMed]

62. Berger, G. Nature of spontaneous tympanic membrane perforation in acute otitis media in children. J. Laryngol. Otol. 1989, 103, 1150-1153. [CrossRef] [PubMed]

63. Torretta, S.; Marchisio, P. Otitis media in children: A proposal for a new nosological classification. Int. J. Pediatr. Otorhinolaryngol. 2017, 93, 174-175. [CrossRef] [PubMed]

64. Marchisio, P.G.; Nazzari, E.; Torretta, S.; Esposito, S.; Principi, N. Medical prevention of recurrent acute otitis media: An updated overview. Expert Rev. Anti Infect. Ther. 2014, 12, 611-620. [CrossRef]

65. Marchisio, P.G.; Esposito, S.; Bianchini, S.; Dusi, E.; Fusi, M.; Nazzari, E.; Picchi, R.; Galeone, C.; Principi, N. Efficacy of Injectable Trivalent Virosomal-Adjuvanted Inactivated Influenza Vaccine in Preventing Acute Otitis Media in Children With Recurrent Complicated or Noncomplicated Acute Otitis Media. Pediatr. Infect. Dis. J. 2009, 28, 855-859. [CrossRef]

66. Marchisio, P.G.; Consonni, D.; Baggi, E.; Zampiero, A.; Bianchini, S.; Terranova, L.; Tirelli, S.; Esposito, S.; Principi, N. Vitamin D Supplementation Reduces the Risk of Acute Otitis Media in Otitis-prone Children. Pediatr. Infect. Dis. J. 2013, 32, 1055-1060. [CrossRef]

67. Man, W.H.; Van Dongen, T.M.; Venekamp, R.P.; Pluimakers, V.G.; Chu, M.L.J.; Van Houten, M.A.; Sanders, E.A.; Schilder, A.G.M.; Bogaert, D. Respiratory Microbiota Predicts Clinical Disease Course of Acute Otorrhea in Children With Tympanostomy Tubes. Pediatr. Infect. Dis. J. 2019, 38, e116-e125. [CrossRef]

68. Liu, C.M.; Cosetti, M.K.; Aziz, M.; Buchhagen, J.L.; Contente-Cuomo, T.L.; Price, L.B.; Keim, P.; Lalwani, A.K. The Otologic MicrobiomeA Study of the Bacterial Microbiota in a Pediatric Patient With Chronic Serous Otitis Media Using 16SrRNA Gene-Based Pyrosequencing. Arch. Otolaryngol. Head Neck Surg. 2011, 137, 664-668. [CrossRef]

69. Frank, D.N.; Spiegelman, G.B.; Davis, W.; Wagner, E.; Lyons, E.; Pace, N.R. Culture-independent molecular analysis of microbial constituents of the healthy human outer ear. J. Clin. Microbiol. 2003, 41, 295-303. [CrossRef]

70. Jervis-Bardy, J.; Rogers, G.B.; Morris, P.S.; Smith-Vaughan, H.C.; Nosworthy, E.; Leong, L.E.X.; Smith, R.J.; Weyrich, L.S.; De Haan, J.; Carney, A.S.; et al. The microbiome of otitis media with effusion in Indigenous Australian children. Int. J. Pediatr. Otorhinolaryngol. 2015, 79, 1548-1555. [CrossRef] 
71. Fagö-Olsen, H.; Dines, L.M.; Sørensen, C.H.; Jensen, A. The Adenoids but Not the Palatine Tonsils Serve as a Reservoir for Bacteria Associated with Secretory Otitis Media in Small Children. mSystems 2019, 4, e00169-e0218. [CrossRef] [PubMed]

72. Johnston, J.; Hoggard, M.; Biswas, K.; Astudillo-García, C.; Radcliff, F.J.; Mahadevan, M.; Douglas, R.G. Pathogen reservoir hypothesis investigated by analyses of the adenotonsillar and middle ear microbiota. Int. J. Pediatr. Otorhinolaryngol. 2019, 118, 103-109. [CrossRef]

73. Ari, O.; Karabudak, S.; Kalcioglu, M.T.; Gunduz, A.Y.; Durmaz, R. The bacteriome of otitis media with effusion: Does it originate from the adenoid? Int. J. Pediatr. Otorhinolaryngol. 2019, 126, 109624. [CrossRef] [PubMed]

74. Chan, C.L.; Wabnitz, D.; Bardy, J.J.; Bassiouni, A.; Wormald, P.-J.; Vreugde, S.; Psaltis, A.J. The microbiome of otitis media with effusion. Laryngoscope 2016, 126, 2844-2851. [CrossRef] [PubMed]

75. Boers, S.A.; De Zeeuw, M.; Jansen, R.; Van Der Schroeff, M.P.; Van Rossum, A.M.C.; Hays, J.P.; Verhaegh, S.J.C. Characterization of the nasopharyngeal and middle ear microbiota in gastroesophageal reflux-prone versus gastroesophageal reflux non-prone children. Eur. J. Clin. Microbiol. Infect. Dis. 2018, 37, 851-857. [CrossRef] [PubMed]

76. Xu, J.; Dai, W.; Liang, Q.; Ren, D. The microbiomes of adenoid and middle ear in children with otitis media with effusion and hypertrophy from a tertiary hospital in China. Int. J. Pediatr. Otorhinolaryngol. 2020, 134, 110058. [CrossRef]

77. Chan, C.L.; Wabnitz, D.; Bassiouni, A.; Wormald, P.-J.; Vreugde, S.; Psaltis, A.J. Identification of the Bacterial Reservoirs for the Middle Ear Using Phylogenic Analysis. JAMA Otolaryngol. Neck Surg. 2017, 143, 155-161. [CrossRef]

78. Krueger, A.; Val, S.; Pérez-Losada, M.; Panchapakesan, K.; Devaney, J.; Duah, V.; DeMason, C.; Poley, M.; Rose, M.; Preciado, D.; et al. Relationship of the Middle Ear Effusion Microbiome to Secretory Mucin Production in Pediatric Patients With Chronic Otitis Media. Pediatr. Infect. Dis. J. 2017, 36, 635-640. [CrossRef] [PubMed]

79. Kolbe, A.R.; Castro-Nallar, E.; Preciado, D.; Pérez-Losada, M. Altered Middle Ear Microbiome in Children With Chronic Otitis Media With Effusion and Respiratory Illnesses. Front. Microbiol. 2019, 9, 1-10. [CrossRef]

80. Kim, S.K.; Hong, S.J.; Pak, K.H.; Hong, S.M. Analysis of the Microbiome in the Adenoids of Korean Children with Otitis Media with Effusion. J. Int. Adv. Otol. 2019, 15, 379-385. [CrossRef]

81. Walker, R.E.; Walker, C.G.; Camargo, C.A., Jr.; Bartley, J.; Flint, D.; Thompson, J.M.D.; Mitchell, E.A. Nasal microbial composition and chronic otitis media with effusion: A case-control study. PLoS ONE 2019, 14, e0212473. [CrossRef] [PubMed]

82. Neeff, M.; Biswas, K.; Hoggard, M.; Taylor, M.W.; Douglas, R.G. Molecular Microbiological Profile of Chronic Suppurative Otitis Media. J. Clin. Microbiol. 2016, 54, 2538-2546. [CrossRef] [PubMed]

83. Minami, S.B.; Mutai, H.; Suzuki, T.; Horii, A.; Oishi, N.; Wasano, K.; Katsura, M.; Tanaka, F.; Takiguchi, T.; Fujii, M.; et al. Microbiomes of the normal middle ear and ears with chronic otitis media. Laryngoscope 2017, 127, E371-E377. [CrossRef] [PubMed]

84. Santos-Cortez, R.L.P.; University of Washington Center for Mendelian Genomics; Chiong, C.M.; Reyes-Quintos, M.R.T.; Tantoco, M.L.C.; Wang, X.; Acharya, A.; Abbe, I.; Giese, A.P.J.; Smith, J.D.; et al. Rare A2ML1 variants confer susceptibility to otitis media. Nat. Genet. 2015, 47, 917-920. [CrossRef]

85. Santos-Cortez, R.L.P.; Hutchinson, D.S.; Ajami, N.J.; Reyes-Quintos, M.R.T.; Tantoco, M.L.C.; Labra, P.J.; Lagrana, S.M.; Pedro, M.; Llanes, E.G.D.V.; Gloria-Cruz, T.L.; et al. Middle ear microbiome differences in indigenous Filipinos with chronic otitis media due to a duplication in the A2ML1 gene. Infect. Dis. Poverty 2016, 5, 97. [CrossRef]

86. Hill, C.; Guarner, F.; Reid, G.; Gibson, G.R.; Merenstein, D.J.; Pot, B.; Morelli, L.; Canani, R.B.; Flint, H.J.; Salminen, S.; et al. The International Scientific Association for Probiotics and Prebiotics consensus statement on the scope and appropriate use of the term probiotic. Nat. Rev. Gastroenterol. Hepatol. 2014, 11, 506-514. [CrossRef]

87. Broek, M.F.L.V.D.; De Boeck, I.; Kiekens, F.; Boudewyns, A.; Vanderveken, O.M.; Lebeer, S. Translating Recent Microbiome Insights in Otitis Media into Probiotic Strategies. Clin. Microbiol. Rev. 2019, 32, 1-33. [CrossRef]

88. Chen, T.Y.; Hendrickx, A.; Stevenson, D.S.; Bird, P.; Walls, T. No evidence from a systematic review for the use of probiotics to prevent otitis media. Acta Paediatr. 2020. [CrossRef] [PubMed]

89. Lappan, R.; Jamieson, S.E.; Peacock, C.S. Reviewing the Pathogenic Potential of the Otitis-Associated Bacteria Alloiococcus otitidis and Turicella otitidis. Front. Cell Infect. Microbiol. 2020, 10, 51. [CrossRef]

(C) 2020 by the authors. Licensee MDPI, Basel, Switzerland. This article is an open access article distributed under the terms and conditions of the Creative Commons Attribution (CC BY) license (http://creativecommons.org/licenses/by/4.0/). 